\title{
UMA DIFÍCIL APROXIMAÇÃO: ESBOÇOS DA PRESENÇA CARTESIANA NO CURSO SOBRE A NATUREZA DE MERLEAU-PONTY
}

\author{
A hard approach: sketches of the Cartesian presence on
}

Merleau-Ponty's course about Nature

José Marcelo Siviero*

Resumo: Trata-se dum recenseamento, a partir dos primeiros capítulos do curso sobre a Natureza (La Nature) de Merleau-Ponty, da presença cartesiana nos escritos e reflexões merleaupontyanas, nos quais se observa uma preparação dos primeiros passos da ontologia tardia do autor de $O$ Visível e o Invisível. Nele, observa-se duas abordagens diferentes da letra cartesiana, que a princípio parecem contraditórias: a abordagem a partir da infinitude de Deus em relação ao homem e a confusão entre a alma e o corpo. Compreender a articulação entre as duas abordagens e como elas se lançam na direção duma mesma leitura é a tarefa deste artigo.

Palavras-chave: Merleau-Ponty, Descartes; Infinito, Substância, Fenomenologia.

\begin{abstract}
This is a census, from the first chapters of Merleau-Ponty's Nature Course (La Nature), from the Cartesian presence in Merleau-Ponty's writings and reflections, in which we observe a preparation of the first steps of late ontology of the author of The Visible and the Invisible. Here we see two different approaches to the Cartesian writings, which at first seem contradictory: the approach from the infinity of God in relation to man and the confusion between the soul and the body. Understanding the articulation between the two approaches and how they launch towards the same reading is the task of this article.
\end{abstract}

Keywords: Merleau-Ponty, Descartes, Infinite, Substance, Phenomenology.

\footnotetext{
* Doutorando em Filosofia pela Universidade de São Paulo - USP. Bolsista CNPq. E-mail: sivierojm@gmail.com
}

\begin{tabular}{|c|c|l|l|c|c|}
\hline intuitio & $\begin{array}{c}\text { ISSN } \\
1983-4012\end{array}$ & Porto Alegre & Vol.10- $\mathrm{N}^{\circ} .2$ & $\begin{array}{c}\text { Dezembro } \\
2017\end{array}$ & p. 130-156 \\
\hline
\end{tabular}


José Marcelo Siviero

Uma difícil aproximação: esboços da presença cartesiana no curso sobre a Natureza de Merleau-Ponty

\section{Introdução}

Há muitos pontos em comum entre as filosofias de Merleau-Ponty e Descartes. Poderíamos afirmar, embora com certas ressalvas e levando em conta o contexto no qual ambas floresceram, que os dois pensadores tiveram duas preocupações basilares: a concepção da filosofia como ciência rigorosa (levando em conta as ressonâncias do projeto husserliano que encontramos em Merleau-Ponty e a preocupação cartesiana em elaborar um novo pensamento que se contrapusesse à tradição escolástica) e o enriquecimento desta com os saberes produzidos pelas ciências da época (como os subsídios captados por Merleau-Ponty junto à psicologia comportamental, à psicanálise e à Gestalttheorie, e a influência dos estudos de mecânica e anatomia de inspiração galilaica no caso de Descartes).

Se há uma semelhança nítida entre os projetos filosóficos, há, por outro lado, uma ruptura profunda entre o tempo e a cultura em que cada uma das filosofias foi concebida. Três séculos separam o autor do Discurso do Método do fenomenólogo contemporâneo. O que, em termos filosóficos, nos coloca numa dificuldade grave, pois a linguagem, o método de leitura e até mesmo as preocupações dum homem de cultura do século XX diferem dramaticamente das de outro nascido na Idade Moderna.

Ora, a presença cartesiana se encontra já nos primeiros escritos de Merleau-Ponty. A abertura de $A$ Estrutura do Comportamento toma para si um problema clássico desenvolvido por Descartes, a saber, a dualidade entre a alma ou mente (res cogitans) e o corpo (res extensa), e a necessidade de estabelecer a relação entre as duas substâncias ${ }^{1}$; questão que é herança direta das preocupações e discussões que orientam o trajeto das Meditações. O tema da dualidade ontológica, contudo, será mais desenvolvido e investigado na Fenomenologia da Percepção $o^{2}$, sob o signo do que o filósofo chama de preconceitos clássicos (préjugées classiques) ${ }^{3}$. Nela se descobre a herança cartesiana que marca todo o pensamento ocidental, isto é, de que há apenas duas maneiras de existir: existe-se como coisa ou como consciência. A tradição filosófica se erigirá sobre este modelo e suas variações, chegando até o pensamento contemporâneo.

\footnotetext{
${ }^{1}$ Como se lê na abertura: "Nosso objetivo é compreender as relações entre a consciência e a natureza- orgânica, psicológica ou mesmo social. Entendemos aqui por natureza uma multiplicidade de acontecimentos exteriores uns aos outros e ligados por relações de causalidade"(SC, p.1).

${ }^{2}$ Particularmente nos caps. 1 e 2. Merleau-Ponty coloca os preconceitos clássicos como assunto principal, nos quais, além da crítica ao pensamento cartesiano, analisa suas consequências confrontando-as com casos clínicos de psicologia e neurologia. Trabalhei longamente essa questão em minha dissertação de mestrado. Cf. SIVIERO, J.M. Motricidade, sensibilidade e desejo: três leituras do corpo na Fenomenologia da Percepção de Merleau-Ponty. São Paulo, 2015. Dissertação (Mestrado em Filosofia). FFLCH, Departamento de Filosofia, Universidade de São Paulo. ${ }^{3}$ Optamos por traduzir préjugés classiques por preconceitos clássicos a fim de melhor expressar qual é a acepção utilizada por Merleau-Ponty. Uma tradução literal por prejuízos clássicos traria dificuldades devido à ambiguidade do termo prejuízo, ligado à economia e finanças. Optamos por preconceito por este ter um sentido mais próximo à filosofia, isto é, exprimindo uma pré-concepção ou um conjunto de pressupostos que operam no interior dum determinado pensamento.
}

\begin{tabular}{|c|c|c|c|c|c|}
\hline intuitio & $\begin{array}{c}\text { ISSN } \\
1983-4012\end{array}$ & Porto Alegre & Vol.10 - No.2 & $\begin{array}{c}\text { Dezembro } \\
2017\end{array}$ & p. 130-156 \\
\hline
\end{tabular}


Contudo, seguindo um traço estilístico (que é, ademais, a principal causa de dificuldades na pesquisa e análise das obras merleau-pontyanas), Merleau-Ponty raramente cita Descartes nominalmente. As referências aparecem sobretudo na menção de questões e conceitos e na retomada de reflexões muito específicas. Isso no que diz respeito às obras propriamente ditas. Já nos cursos ministrados no Collège de France, dentre os quais se encontra o do conceito de Natureza, Descartes aparece explicitamente citado. Quais traços da leitura merleau-pontyana podemos observar nessas anotações?

O curso sobre a Natureza surge num momento em que o projeto ontológico merleau-pontyano começa a se delinear em sua obra, após os estudos sobre a linguagem e o mundo da cultura, trajeto de pensamento que pouco a pouco abre mão da fenomenologia e se aproxima duma indagação sobre o ser da percepção e do mundo percebido e sobre a instituição de sentido que é sua consequência principal. Por isso, ainda que num âmbito conceitual, Merleau-Ponty se dedicará à confrontação deste projeto ontológico com os conceitos clássicos de Natureza, dentre eles o cartesiano, que muita influência exerceu sobre o pensamento moderno e que encontra ecos no pensamento contemporâneo.

Ora, a aparição de Descartes nos escritos de Merleau-Ponty diz respeito, segundo Renaud Barbaras, uma espécie de "meditação do cartesianismo", seguida duma "confrontação com a fenomenologia husserliana" ${ }^{5}$. Desde o início assume uma postura crítica, embora não busque uma

${ }^{4}$ BARBARAS, Renaud. De l'être du phénomène: sur l'ontologie de Merleau-Ponty. Grenoble: Éditions Jérôme Millon, 2001, p. 103.

${ }^{5}$ A escolha da expressão "meditação do cartesianismo", cunhada por Barbaras e utilizada frequentemente em várias passagens de sua obra, indica claramente uma referência às Meditações Cartesianas de Husserl, que retomam as ideias de Descartes, ao mesmo tempo em que recusam a doutrina cartesiana (mais precisamente a metafísica da substância). Husserl se inspira em Descartes para conceber uma Fenomenologia Transcendental (que difere das fenomenologias de Kant e Hegel, ambas de caráter epistemológico), pois o que ela visa é uma resposta filosófica a um cenário de crise que assolava, nos princípios do século XX, todo o mundo filosófico, fruto do esgotamento e da saturação levada a cabo pelo inchaço do neokantismo, o hegelianismo e do positivismo. Essa crise é basicamente uma perda da tarefa inicial da filosofia (enquanto ciência universal), ou seja, duma reflexão rigorosa sobre problemas universais e do confronto profícuo entre pensamentos e conceitos diferentes entre si. Nesta época, a filosofia se enreda numa tarefa crítica, de indagação acerca das condições de possibilidade do pensamento, e não do exercício do pensamento em si. É a fundamentação desta fenomenologia que leva Husserl a escrever as Meditações Cartesianas, que não são a reiteração ou a restauração do pensamento cartesiano, mas uma reflexão a partir das mesmas diretrizes, dos mesmos princípios e, podemos afirmar, dos mesmos acertos que orientaram Descartes durante o seu ato meditativo, com visas à reforma do pensamento e da razão. Husserl demarca desde o início o âmbito de suas meditações: não se trata de defender ou corroborar, mas seguir o mesmo percurso trilhado pelas Meditações sobre Filosofia Primeira. A Fenomenologia Transcendental husserliana marca uma grande diferença em relação à filosofia cartesiana pois, em sua formulação inicial, tem de "rejeitar quase no seu todo [...] o bem conhecido teor doutrinário da filosofia cartesiana" (HUSSERL, 2013, p.39). Porém, a Husserl interessa recuperar o escopo dos escritos cartesianos, a saber, a tarefa duma "completa reforma da Filosofia numa ciência baseada na fundamentação absoluta" (HUSSERL, 2013, p.39). Tal fundamentação se dará, no que Husserl tenta retomar, através da dúvida metódica e de todo conhecimento que não fosse passível de seu escrutínio. Portanto, na trilha das Meditações, Husserl busca efetuar "um regresso ao ego filosofante num segundo e mais profundo sentido, um regresso ao ego das cogitationes puras" (HUSSERL, 2013, p.40). Aparentemente, Descartes consegue realizar o intento de afastar todos os preconceitos e pressuposições mundanas do ego cogito; todas as atividades mentais, como o raciocínio, a percepção, a imaginação, a memória, a faculdade de julgar, reduzem-se a cogitationes. Porém, Husserl constata que a epoché não se realiza por completo em Descartes, pois, ao contrário dum Ego Transcendental, suas Meditações resvalam numa

\begin{tabular}{|c|c|l|l|c|c|}
\hline intuitio & $\begin{array}{c}\text { ISSN } \\
1983-4012\end{array}$ & Porto Alegre & Vol.10- $\mathrm{N}^{\circ} .2$ & $\begin{array}{c}\text { Dezembro } \\
2017\end{array}$ & p. 130-156 \\
\hline
\end{tabular}


refutação total: trata-se, a rigor, de investigar as articulações internas do cartesianismo, a gênese e consolidação de suas teses, a evolução de um pensamento que se coloca como constituinte. Há, segundo o comentador, uma "diplopia" no cerne do pensamento cartesiano:

A filosofia cartesiana é caracterizada fundamentalmente por uma dualidade de pontos de vista. Nela, o mundo é tomado essencialmente segundo a alternativa do Ser e do Nada, isto é, como puro naturado, que assim se reporta a Deus, puro naturante: ele é

substancialização do pensamento. Escreve Husserl que "infelizmente, é isso que se passa em Descartes com a viragem singela mas fatal, que faz do ego uma substantia cogitans, um mens sive animus humano separado, e um ponto de partida para inferências segundo o princípio causal, numa palavra, a viragem pela qual ele se tornou o pai do contrassenso (que não podemos ainda tornar visível) do Realismo Transcendental" (HUSSERL, 2013, p.62). A fatalidade é que, preocupado em estabelecer um fundamento para a filosofia que pretendia iniciar ligado apoditicidade da matemática e da geometria, Descartes só encontrou a solução para seus próprios problemas no argumento da causalidade, de que o Cogito é causa das suas cogitationes. A tese de Husserl é a de que Descartes realizou a tarefa duma fundamentação racional, mas errou quando, no lugar de investir a subjetividade dum caráter transcendental, apelou à saída (mais tradicional) da metafísica da substância. É no terreno desta contradição que se move Barbaras em sua leitura de Merleau-Ponty. Embora se localize sob sua zona de influência, Merleau-Ponty ultrapassa a posição husserliana porque se afasta do Ego Transcendental e, nesta tomada de posição, confronta ao mesmo tempo as limitações do próprio Husserl e do cartesianismo que lhe serve de inspiração estilística e metodológica. Merleau-Ponty começa contatando que "a fenomenologia se deixa praticar e reconhecer como maneira ou como estilo; ela existe como movimento antes de ter chegado a uma inteira consciência filosófica" (PhP, p.2). Tudo se deve à atitude (cartesiana) de Husserl de atribuir o caráter de absoluto ao Ego Transcendental; o que Husserl faz é, como dissemos anteriormente, negar a metafísica da substância, mas conservar a dúvida metódica e o Cogito. Três pontos da filosofia husserliana serão criticados por Merleau-Ponty: a redução fenomenológica, a redução eidética e a intencionalidade. Ele começa observando que a redução fenomenológica, enquanto epoché que coloca em suspenso os pressupostos da atitude natural, "seria idealista, no sentido de um idealismo transcendental que trata o mundo como uma unidade de valor indiviso entre Paulo e Pedro, no qual suas perspectivas se recobrem, [...] em cada um deles um feito de consciências pré-pessoais cuja comunicação não representa problema, sendo exigida pela própria definição da consciência, do sentido ou da verdade" (PhP, p.7). A rigor, essa redução depuraria o Lebenswelt de sua espessura e profundidade, transformando-o em pura significação. $\mathrm{O}$ que nos leva inexoravelmente à redução eidética, a uma relação entre essências (em sentido fenomenológico e não cartesiano, é importante ressaltar). Merleau-Ponty subverte a tarefa inicial husserliana de se buscar as essências enquanto correlatos da consciência (ou seja, cogitationes, em sentido cartesiano) e as restitui ao que seria o escopo da fenomenologia, isto é, o imperativo de ir "às coisas mesmas" (zu dem selbsten Sachen): de modo que "buscar a essência da consciência [...] será reencontrar essa presença efetiva de mim a mim, o fato de minha consciência, que é aquilo que querem dizer, finalmente, a palavra e o conceito de consciência" ( $\mathrm{PhP}$, p.13). As teses husserlianas não são exatamente refutadas, mas ressignificadas e refundadas dentro de seu próprio campo. Sendo assim, a intencionalidade não é a relação da consciência com seus correlatos (em termos cartesianos, do Cogito com as cogitationes), mas posição do sujeito no seio do mundo que o abarca: no que tange à intencionalidade, "trata-se de reconhecer a própria consciência como projeto do mundo, destinada a um mundo que ela não abarca nem possui, mas em direção ao qual ela não cessa de se dirigir" (PhP, p.15). Podemos falar duma ruptura entre Merleau-Ponty e Husserl? Podemos estender essa ruptura também ao cartesianismo? Certamente que não. Toda a Fenomenologia da Percepção se move num terreno fenomenológico-cartesiano (haja vista os tópicos que discute em suas três partes, como a polarização entre subjetivismo e objetivismo e entre corpo e consciência) e o ensaio Le philosophe et son ombre (de Signes) explicita o diálogo incessante e fecundo entre Merleau-Ponty e Husserl. O que observamos é uma espécie de rompimento branco, isto é, um afastamento (não conflituoso) das primeiras teses de Husserl, ao mesmo tempo em que se opera uma aproximação com as ideias de sua obra tardia (como o resgate do Lebenswelt como solo fundamental de todo pensamento e ação humana, que é o motor da escrita da Krisis). Merleau-Ponty é filósofo, professor e pesquisador, mas aqui o seu papel é de leitor: perscruta o todo do pensamento dum autor, critica o que não se alinha com sua reflexão, recorta o que a anima, constrói seu pensamento a partir do que lhe é oferecido, e, tal como o autor lido, empreende a mesma tarefa racional. A meditação nada mais é que leitura meditante, isto é, entrecruzamento entre o que foi dito e não dito, entre o que é literal e o que é velado, entre o explícito e o pressuposto.

\begin{tabular}{|c|c|c|c|c|c|}
\hline intuitio & $\begin{array}{c}\text { ISSN } \\
1983-4012\end{array}$ & Porto Alegre & Vol.10- o.2 & $\begin{array}{c}\text { Dezembro } \\
2017\end{array}$ & p. 130-156 \\
\hline
\end{tabular}


exatamente o que deve ser, o que ele já é necessariamente, e aparece então 'sem falhas nem fissuras', ou seja, sem profundidade ${ }^{6}$.

Assim, a Natureza é encarada tal como aparece sob a luz natural: partes extra partes, regida por leis mecânicas eternas e invariáveis, sob a figura da extensão- o ser. A ela se oporá o sujeito pensante- o Nada (a consciência em linguagem sartreana), fonte de clareza e distinção, que a transforma em puro objeto intelectual e assim desvenda suas leis tais como foram prescritas por Deus- por isso ela é puro naturado e jamais um naturante (na linguagem espinosana). Há, portanto, uma diferença substancial entre sujeito e mundo. Será nessas linhas mestras que Merleau-Ponty lerá a concepção cartesiana de Natureza.

\section{Deus infinito e Natureza finita: a primeira inspiração cartesiana}

O curso sobre a Natureza ministrado por Merleau-Ponty compreende duas partes, com temas distintos, recolhidas através de dois cadernos dum estudante desconhecido e cotejadas com anotações pessoais do filósofo para a preparação das aulas. Na primeira parte, são estudadas as variações de acepção do conceito de Natureza (num panorama histórico que vai das concepções aristotélicas e estoicas até as ideias de Husserl), enquanto que o objeto da segunda é a passagem da animalidade ao corpo humano e da natureza à cultura. A presença de Descartes se faz observar nas duas partes, embora em perspectivas distintas e sob leituras diferentes.

O que Merleau-Ponty recorta em Descartes é a sua relação com o pensamento do Infinito (associado a Deus) e as influências da cultura judaico-cristã em sua filosofia. Contudo, como veremos mais adiante, seu pensamento se divide em duas inspirações diferentes.

Pensando sobre a historicidade do conceito de Natureza, Merleau-Ponty se faz uma série de perguntas visando escapar a uma mera análise do sentido da palavra e à busca dum suposto significado secreto e único que, por si só, esclareceria e esgotaria tudo o que se pode compreender por Natureza. Dentre algumas questões, Merleau-Ponty se indaga se é possível reconhecer na linguagem uma "vida que não seria nem fortuita, nem um desenvolvimento lógico imanente" (N, p.19). A saída para esse impasse inicial é a reconstituição dum sentido primordial, e não lexical, da palavra Natureza.

Escavando a origem etimológica do termo, Merleau-Ponty descobre uma semelhança de sentido entre os radicais de physis e natura: "em grego, a palavra 'Natureza' vem do verbo $\phi v \omega[p h y ́ o]$, que faz alusão ao vegetal; a palavra latina vem de nascor, nascer, viver; com ênfase no primeiro sentido, que é mais fundamental" (N, p.19). A analogia com o vegetal alude a uma vida anterior à consciência, que não necessita dela para se desenvolver, enquanto que o nascimento, em essência, remete a um ato impessoal,

${ }^{6}$ BARBARAS, Renaud. De l'être du phénomène: sur l'ontologie de Merleau-Ponty. Grenoble: Éditions Jérôme Millon, 2001, p. 103.

\begin{tabular}{|c|c|c|c|c|c|}
\hline intuitio & $\begin{array}{c}\text { ISSN } \\
1983-4012\end{array}$ & Porto Alegre & Vol.10- $\mathrm{N}^{\circ} .2$ & $\begin{array}{c}\text { Dezembro } \\
2017\end{array}$ & p. 130-156 \\
\hline
\end{tabular}


Uma difícil aproximação: esboços da presença cartesiana no curso sobre a Natureza de Merleau-Ponty

anterior à memória e, portanto, a-histórico, necessitando duma visão prospectiva (e já objetivada) para se constituir numa história pessoal. Assim, restituindo o sentido original da palavra, a Natureza se refere a algo que é anterior ao sujeito, que não depende dele para existir, mas que é seu suporte e condição de possibilidade da vida e do pensamento. Em outras palavras, "é natureza o que tem um sentido, sem que esse sentido seja posto pelo pensamento" (N, p.19).

Sem a necessidade do pensamento, há na Natureza uma interioridade não tética e uma autoprodução intrínseca. A Natureza se mantém e se determina por si mesma, e por isso Merleau-Ponty evocará a diferença entre o natural e o acidental, tão cara à tradição filosófica.

Para Merleau-Ponty, a Natureza terá um significado eminentemente primordial; é natural o que não é instituído nem construído sobre o mundo sensível, sendo, portanto, anterior à presença dum sujeito percipiente. O que quer dizer: trata-se de algo cujo significado ultrapassa em muito o que ele chamava de pré-objetivo em 1945, na Fenomenologia da Percepção, pois o pré-objetivo ainda dependia da presença do sujeito que percebe, nascendo do contato imediato e espontâneo do corpo com o meio que o circunda ${ }^{7}$. Ao recortar o tema de seu curso, Merleau-Ponty explicita a necessidade duma nova ontologia, que supere os dilemas duma filosofia ainda marcada pelo idealismo e pela dualidade cartesiana. Deste modo, propor que "a Natureza é um objeto enigmático, um objeto que não é totalmente objeto; em resumo, ela não está inteiramente à nossa frente. Ela é nosso solo, não o que está adiante, mas o que nos suporta" (N, p.20) é não apenas uma tentativa de obter a arché do mundo, mas sim a redescoberta da Natureza enquanto physis no sentido clássico, isto é, gênese do mundo sensível.

A ideia da Natureza como um objeto partes extra partes é antiga, remontando ao atomismo materialista de Lucrécio. É a concepção de que "cada parcela de ser é uma totalidade fechada sobre seu próprio 'despojamento'. Há um parentesco entre a ideia do átomo e o individualismo" (N, p.25). Porém, há que se ressaltar que Descartes é contrário à ideia de átomo tal como fora concebida na Antiguidade ${ }^{8}$;

\footnotetext{
${ }^{7}$ Como se lê na abertura da segunda parte da Fenomenologia da Percepção: "o corpo próprio está no mundo assim como o coração no organismo; ele mantém o espetáculo visível continuamente em vida, anima-o e alimenta-o interiormente, forma com ele um sistema" (PhP, 273). A camada pré-objetiva da experiência depende, portanto, dum corpo percipiente que anime o espetáculo; resta ainda um traço (mitigado) de idealismo na primeira fase da filosofia de Merleau-Ponty. O mundo não é exatamente posto pela consciência, mas por um corpo dotado de motricidade e sensibilidade. O curso sobre a Natureza se distancia dessa interpretação e conduz sua reflexão ao que posteriormente será a Carne.

${ }^{8}$ É inusitada (para não se dizer controversa) a aproximação que Merleau-Ponty faz entre Descartes e o atomismo clássico. Trata-se duma corrente e dum autor que defendem teses opostas; a noção antiga de átomo também dizia respeito a uma realidade partes extra partes, tecida por minúsculos corpúsculos simples e indivisíveis, externos uns aos outros, que se comporiam e decomporiam sem que sua natureza individual fosse alterada, ou seja, passíveis de análise e síntese, da mesma maneira como, em Descartes, se organizariam e dividiriam as várias partes do corpo e da Natureza. Todavia, Descartes não é partidário do atomismo antigo. Nem mesmo sua filosofia daí tira inspiração, muito pelo contrário: as teses cartesianas contradizem os postulados atomistas em seu cerne, sem qualquer possibilidade de conciliação. Como lemos na doxografia de Leucipo registrada por Diógenes Laércio, "todas as coisas são ilimitadas e se mudam umas nas outras. O todo é ao mesmo tempo vazio e cheio de corpos. Os mundos se formam quando os corpos despencam no vácuo e se entrelaçam uns com os outros; [...] Este [o agregado de corpos] é
}

\begin{tabular}{|c|c|c|c|c|c|}
\hline intuitio & $\begin{array}{c}\text { ISSN } \\
1983-4012\end{array}$ & Porto Alegre & Vol.10 $-\mathrm{N}^{\circ} .2$ & $\begin{array}{c}\text { Dezembro } \\
2017\end{array}$ & p. 130-156 \\
\hline
\end{tabular}


José Marcelo Siviero

Uma difícil aproximação: esboços da presença cartesiana no curso sobre a Natureza de Merleau-Ponty

afirmá-la validaria a ideia de vácuo ${ }^{9}$, o que seria absurdo para o autor das Meditações. Contrário ao atomismo, Descartes tampouco é o criador da noção de partes extra partes, embora sustente que um dos postulados da extensão é o fato de que os corpos não se interpenetram; ele antes toma partido no debate que domina a ciência e a cultura de sua época, que presencia uma situação em que "não são as descobertas científicas que provocaram a mudança da ideia de Natureza. É a mudança da ideia de Natureza que permitiu essas descobertas" (N, p.25). Trata-se não da restituição e adoção do atomismo clássico, mas da

distendido, qual uma membrana, envolvendo em si mesmo corpos de todos os tipos; o turbilhão desses corpos operando uma contração do centro, a membrana externa tornando-se fina, os corpos contíguos não cessando de juntos afluir em virtude da fluidez do turbilhão" (DIOGÈNE LAËRCE, 1999, pp.1072-1073). Mas por que MerleauPonty aproximaria Descartes de filósofos que ele mesmo rejeitava? No recorte que faz, o autor do Curso sobre a Natureza quer encontrar uma noção primitiva de individualismo; como se trata dum curso voltado ao estudo da história do termo "Natureza", Merleau-Ponty cava suas raízes no atomismo antigo, o que o leva a declarar que "não há sociedade natural; a sociedade é uma criação utilitária. [...] Epicuro não reconhece sentimentos naturais entre pais e filhos" (N, p.25). Os átomos para Epicuro são corpúsculos independentes e fechados em si mesmos, de modo que todos os corpos "são indestrutíveis e imutáveis, se é verdade que todas as coisas não são destinadas a se destruir no não ser; ao contrário, possuem eles a força de subsistir nas dissoluções dos compostos, sendo plenos por sua natureza" (EPICURO apud DIOEGĖNE LAËRCE, 1999, p.1268). A relação que Merleau-Ponty estabelece entre a concepção cartesiana de Natureza e o atomismo antigo é analógica: há similaridades pontuais e alguma convergência, mas nunca identidade entre ambos os pensamentos.

${ }^{9}$ A res extensa nega por completo a infinitude do átomo (pois é da natureza da extensão ser limitada) e o vácuo entre as partículas (pois toda coisa extensa é limitada por outra coisa extensa, sem que um espaço vazio se interponha entre elas). O que caracteriza o corpo ou substância extensa em geral? Ora, não se trata das qualidades sensíveis a ele atribuídas, nem ao conjunto de percepções que o entendimento dele retira, mas apenas "saberemos que a natureza da matéria ou do corpo em geral não consiste em ser uma coisa dura, pesada ou colorida, ou que afecta os sentidos de qualquer outra maneira, mas que é apenas uma substância extensa em comprimento, largura e altura" (DESCARTES, 1997, p.60). Sendo, portanto, dotado duma figura (e, por conseguinte, de movimento), o corpo só poderá ser limitado por outro corpo que, como ele, também será extenso. O que nos leva a concluir que "quando examinamos um corpo, podemos pensar que não tem si nenhuma destas qualidades [sensíveis] [...] que tem tudo o que faz deles um corpo [comprimento, largura e altura] [...]; donde também se segue que para existir o corpo não tem absolutamente necessidade dessas qualidades [sensíveis]" (DESCARTES, 1997, p.61). A ideia do vácuo (vazio) e da rarefação, que supõem que haja um interstício entre os corpos que não seria preenchido por nada extenso (exatamente o que defendiam os atomistas quando afirmavam que os átomos necessitavam dum espaço vazio para se moverem, colidirem e se agregarem), é apenas uma opinião errônea, derivada do hábito e dos preconceitos adquiridos, pois nela "algumas pessoas [...] imaginam que um corpo tem mais extensão quando está rarefeito do que quando está condensado" (DESCARTES, 1997, p.1). Mas quais as origens dessa opinião? A distinção entre rarefação e condensação ocorre apenas quando há uma mudança de figura do corpo extenso, isto é, uma mudança que se percebe apenas pelo seu aspecto sensível, como mudança em seu volume, peso, massa, etc, sem que haja qualquer alteração em sua natureza ou essência (por isso o pedaço de cera das Meditações poderá mudar de forma, volume e cor, mas sempre será uma coisa extensa). Quando Descartes escreve que "sempre que virmos um corpo que está rarefeito, devemos pensar que há muitos intervalos entre as suas partes, que são preenchidas por qualquer outro corpo e que, quando condensado, as suas próprias partes estão mais próximas umas das outras" (DESCARTES, 1997, p.61). Os intervalos que dilatariam tal corpo seriam preenchidos também por algo extenso (o ar, por exemplo), também dotado dos atributos de comprimento, largura e altura, o que nos leva a deduzir que o espaço também possui os mesmos atributos. Elimina-se, portanto, toda e qualquer ideia de vácuo. Por conseguinte, tendo o espaço os mesmos atributos dos corpos extensos, nada impede que estes não sejam divididos e fracionados indefinidamente, da mesma maneira com que são aumentados e dilatados. A noção de átomo, como menor parte indivisível, torna-se impossível na filosofia cartesiana: "pois por mais pequenas que as suas partes sejam, todavia- e porque é necessário que sejam extensas- pensamos que não há sequer uma de entre elas que não possa dividir-se em duas ou noutras ainda mais pequenas; donde se segue que são divisíveis" (DESCARTES, 1997, p.68). Segundo a concepção antiga, o átomo não possuiria nem comprimento, nem largura e nem extensão, sendo, portanto, ontologicamente diferente dos corpos extensos; o que, para Descartes, é absurdo.

\begin{tabular}{|c|c|c|c|c|c|}
\hline intuitio & $\begin{array}{c}\text { ISSN } \\
1983-4012\end{array}$ & Porto Alegre & Vol.10 - No.2 & $\begin{array}{c}\text { Dezembro } \\
2017\end{array}$ & p. 130-156 \\
\hline
\end{tabular}


Uma difícil aproximação: esboços da presença cartesiana no curso sobre a Natureza de Merleau-Ponty

contestação da visão finalista e qualitativa ${ }^{10}$, de inspiração aristotélica e estoica. Porém, Descartes não rejeita por completo o discurso finalista. O que ocorre é que essa finalidade é escamoteada em favor dum Deus que é identificado com o conceito de infinito.

Sendo o infinito ontologicamente diverso do finito, na Natureza surge a divisão entre naturante (Deus) e naturado (as coisas criadas): "a partir desse momento, a Natureza se desdobra em um naturante e um naturado. É em Deus então que se refugia tudo o que podia ser interior à Natureza. $O$ sentido se refugia no naturante; o naturado se torna produto, pura exterioridade" (N, p.26, grifos do autor).

Mas qual conceito de Deus opera em Descartes? Lembremos que o Deus cartesiano é, antes de tudo, infinito; não sofre das limitações do pensamento e da extensão e, sendo ontologicamente superior a eles, pode criá-los como substâncias finitas. Sendo infinitude e perfeição, em Deus não há qualquer separação entre causa e efeito; a vontade e o entendimento são indiscerníveis, pois, enquanto substância perfeita (tomando-se a substância em sentido lato e clássico), ela existe por si mesma, é causa de si mesma ao mesmo tempo em que é seu efeito. Isso permite a Merleau-Ponty comentar que para Descartes "o Mundo produzido por um Deus de tal natureza é constituído na ordem da finalidade. Nada do que Deus produz não está imprevisto por ele, os efeitos são dados com as causas" (N, p.26).

Porém, o que Merleau-Ponty quer dizer com "ordem da finalidade"? Não estará ele retornando a Aristóteles através duma contradição explícita em sua fala? Por que há então uma diferença entre o finalismo aristotélico e a concepção cartesiana se ambos não disfarçam uma teleologia aparente? Um erro grosseiro, talvez advindo das imprecisões das notas registradas?

Ora, o que a princípio se mostra como uma contradição na letra do texto é, na verdade, um outro emprego do termo "finalista". Há, intrinsecamente, uma finalidade expressa no mundo; mas essa finalidade muda de sentido quando distinguimos o Deus infinito de Descartes do Motor Imóvel de Aristóteles. Merleau-Ponty introduz o seguinte questionamento a partir dessa cisão: "mas, se o mundo é eminentemente finalista, a finalidade não exprime o que se passa em Deus. Em Deus, fins e meios são indiscerníveis, seu acordo é evidente. Deus não persegue fins, pois nele não há anterioridade do Todo sobre as partes" (N, p.26). Em suma, para Deus, que cria o mundo inteiro num ato único, que enxerga perfeitamente o Todo ordenado, não há necessidade de se pensar as finalidades secretas duma Natureza já totalmente prevista e desvelada.

\footnotetext{
${ }^{10} \mathrm{Tal}$ é o assunto do primeiro capítulo do curso. Nele se lê que "Aristóteles insiste na ideia duma orientação em direção a um tipo, uma ordem, um destino. Assim, quando Aristóteles diz que a natureza dos corpos leves é subir, uma ideia de destinação qualitativa é ligada à Natureza. [...] ela [a Natureza] é a realização, mais ou menos bemsucedida, desta destinação qualitativa dos corpos" (N, p.23, grifos do autor). A finalidade é aqui inerente ao ser dos corpos, tendo sua causa final subordinada ao Primeiro Motor Imóvel, não havendo, portanto, um espaço quantitativo que possibilitaria tais movimentos e modificações. A concepção estoica, segundo Merleau-Ponty, "é a ideia duma simpatia, duma ação a distância entre as partes do mundo, a ideia dum Destino, duma ligação (e não duma conexão das causas)" (N, p.23, grifos do autor).
}

\begin{tabular}{|c|c|c|c|c|c|}
\hline intuitio & $\begin{array}{c}\text { ISSN } \\
1983-4012\end{array}$ & Porto Alegre & Vol.10- $\mathrm{N}^{\circ} .2$ & $\begin{array}{c}\text { Dezembro } \\
2017\end{array}$ & p. 130-156 \\
\hline
\end{tabular}


Uma difícil aproximação: esboços da presença cartesiana no curso sobre a Natureza de Merleau-Ponty

Resta que a finalidade é delegada ao homem. Ente finito e imperfeito, mistura confusa de corpo e consciência, que não abraça o Todo mas experimenta apenas as suas partes, há sentido em se falar duma finalidade expressa nas coisas para quem dele tem uma experiência fragmentada, por vezes confusa e sempre em vias de se completar. "Daí se segue que a Natureza é, à imagem de Deus, senão infinita, ao menos indefinida; ela perde seu interior, ela agora é a realização exterior de uma racionalidade que está em Deus" (N, p.27). Nunca uma imagem foi tão precisa para resumir a visão de Descartes como a da máquina ou do relógio: mescla de mecanismo e artificialismo, regido por movimentos internos, num sistema em que cada peça possui uma lei de funcionamento que depende e sustenta os mecanismos adjacentes; necessita ainda de um artesão que a projete e execute, que domine e planeje seus fins, mas que seja exterior à sua obra.

Em seu interior, a Natureza não tende à perfeição dum Deus que a anima por dentro, nem suas partes seriam impelidas por uma finalidade embutida em sua essência. A partir da filosofia de Descartes

a Natureza torna-se então sinônimo de existência em si, sem orientação, sem interior. Não há mais orientação. O que se pensava como orientação é mecanismo. A divisão aparente da Natureza vem a ser imaginativa e só resulta das leis. Como a Natureza é partes extra partes, só o todo existe verdadeiramente (N, p.27).

Essa ideia tem como principal consequência a concepção da Natureza como sistema de leis que se autoimplicam e se autodeterminam mutuamente. O mundo não depende da vontade arbitrária de Deus, mas sim do jogo e da interação entre as leis da matéria, isto é, de leis basicamente mecânicas. Todos os movimentos perdem o télos que os guiava em favor da kínesis em sentido amplo. A Natureza perde qualquer interioridade, que está contida apenas em Deus. Merleau-Ponty chega ao extremo de afirmar que, caso o mundo fosse criado a partir do caos, seriam essas leis eternas que o guiariam à ordem ${ }^{11}$.

Assim, conclui que "se Deus é infinito, disso resultam certas leis, leis de todo Mundo possível. A Natureza é o autofuncionamento das leis que derivam da ideia de infinito" (N, p.27). Essa é a primeira inspiração cartesiana exposta no curso, fundamentada na ideia dum Deus infinito e na exterioridade total

\footnotetext{
${ }^{11}$ Do Deus eterno derivam leis eternas e necessárias, tais como as leis da geometria. Desta maneira, Descartes limita a potência e a eficácia da razão, pois, ao deduzir e demonstrar racionalmente as leis que regem os fenômenos naturais na parte V do Discurso do Método, conclui que "de todas essas coisas não queria inferir que este mundo tenha sido criado do modo que eu propunha, pois é bem mais verossímil que, desde o começo, Deus o tenha feito tal como devia ser. [...] a ação pela qual agora ele o conserva é exatamente a mesma pela qual o criou" (DESCARTES, 1996, p.51). É Deus, portanto, quem confere racionalidade ao mundo; ao homem compete apenas desvendar, deduzir e demonstrar essas leis eternas, nas quais estão inseridas as leis geométricas, aritméticas e causais. Neste ponto Merleau-Ponty cita Descartes quando ele afirma que "mostrei quais eram as leis da natureza; e, sem apoiar as minhas razões em nenhum outro princípio, que não o das perfeições infinitas de Deus, procurei demonstrar todas aquelas sobre as quais pudesse haver alguma dúvida, e mostrar que elas são tais que, mesmo que Deus houvesse criado muitos mundos, não poderia haver nenhum onde elas deixassem de ser observadas. Depois disso, mostrei como a maior parte da matéria desse caos devia, em decorrência dessas leis, dispor-se e arranjar-se de um certo modo que a tornasse semelhante aos nossos céus" (DESCARTES, 1996, p.49). O homem é racional, mas sua racionalidade está fundada fora de si, sendo ontologicamente inferior a Deus. A primeira inspiração cartesiana se nutre desta constatação.
}

\begin{tabular}{|c|c|c|c|c|c|}
\hline intuitio & $\begin{array}{c}\text { ISSN } \\
1983-4012\end{array}$ & Porto Alegre & Vol.10 - No.2 & $\begin{array}{c}\text { Dezembro } \\
2017\end{array}$ & p. 130-156 \\
\hline
\end{tabular}


entre as partes da Natureza, e Merleau-Ponty o faz para demonstrar como a ideia moderna de Natureza se constitui e como se torna um modelo para as perspectivas futuras.

A ideia do Deus infinito se encontra na Terceira Meditação. Nela, o texto de Descartes realiza um movimento que consuma o que vinha sendo desenvolvido nas meditações anteriores ${ }^{12}$ : após tornar todo o mundo sensível e os afetos da mente duvidosos e de descobrir o Cogito como primeira certeza indubitável através do exercício da dúvida hiperbólica, Descartes faz a prova ontológica da existência de Deus. Porém, seu trajeto é peculiar: começa na lógica e termina na ontologia. Toda sua reflexão gravita ao redor dos conceitos de perfeição, infinito e eternidade, retirando deles, contudo, todo e qualquer significado religioso e místico, e lhes instituindo uma significação metafísica.

Nesta meditação, Descartes recenseia as várias atividades e faculdades do pensamento, tais como a capacidade de formar imagens (tanto de coisas reais quanto imaginárias) e as faculdades de julgar, querer, afirmar, negar, temer, etc., distinguindo as representações como pertencendo à imaginação e os juízos à razão.

No que se refere ao critério de verdade dessas imagens e representações, elas só poderão ser consideradas falsas ou verdadeiras conforme se refiram a um objeto exterior. Em si mesmas, essas operações da consciência podem ser consideradas verdadeiras, pois o Cogito não se engana nem comete equívocos em sua atividade de pensar:

Agora, no que se refere às ideias, se consideradas em si mesmas e não referidas às coisas a que se reportam, não podem ser propriamente falsas. Pois, quer imagine uma cabra ou uma quimera, não é menos verdadeiro que imagino tanto uma quanto a outra. E, também, não há que temer falsidade alguma na própria vontade ou nos afectos, pois, embora eu possa almejar coisas más ou até coisas que não se encontram em parte alguma, não é por isso menos verdadeiro que as almejo ${ }^{13}$.

O que lhe permite concluir que, entre o variado rol de ideias engendradas pela mente, há as que são inatas (existem na mente sem o apoio da experiência, como as ideias de perfeição e eternidade), adventícias (que vêm de objetos externos à consciência, como os dados da sensibilidade) e inventadas (fruto da imaginação, como as quimeras e os sonhos). O que nos interessa mais propriamente aqui são as ideias inatas, dentro das quais se incluirá a do Deus infinito.

Descartes define as ideias inatas como aquelas que independem da vontade ou dum objeto exterior para serem geradas. Além disso, há um escalonamento entre as ideias conforme se refiram às substâncias: as que se referem à extensão são inferiores às que se referem ao pensamento e vice-versa. Desta maneira, "não há dúvida de que as que mostram substâncias são algo mais e contêm, por assim dizer, mais

\footnotetext{
${ }^{12}$ A dúvida hiperbólica e sua aplicação como método está localizada mais precisamente na Primeira Meditação, enquanto que a descoberta e determinação do Cogito se localiza na Segunda Meditação.

${ }^{13}$ DESCARTES, René. Meditações sobre Filosofia Primeira. Trad. de Fausto Castilho. Campinas: UNICAMP, 2004, p. 75.
}

\begin{tabular}{|c|c|l|l|c|c|}
\hline intuitio & $\begin{array}{c}\text { ISSN } \\
1983-4012\end{array}$ & Porto Alegre & Vol.10- $\mathrm{N}^{\circ} .2$ & $\begin{array}{c}\text { Dezembro } \\
2017\end{array}$ & p. 130-156 \\
\hline
\end{tabular}


realidade objetiva, isto é, participam por representação de mais graus de ser ou de perfeição"14 ${ }^{15}$. A ideia dum Deus infinito é não apenas inata, mas "seguramente tem em si mais realidade objetiva do que as ideias pelas quais se mostram as substâncias finitas"16. Entre o infinito e o mundo partes extra partes há um abismo, e um abismo ontológico: a diferença não é apenas qualitativa.

Mas quais seriam as implicações da descoberta do Deus infinito enquanto ideia inata para a concepção merleau-pontyana da primeira inspiração cartesiana? Quais conclusões podemos tirar sobre a exterioridade que há entre Deus e o mundo por ele criado, ou entre o Todo e as partes?

Dentre essas ideias, Descartes observa que, em se tratando das representações, as ideias variam conforme o grau de realidade objetiva que trazem em si, isto é, a semelhança que mantêm com os objetos que representam, ou seja, quanto mais representam a realidade formal do ideado ${ }^{17}$. Quanto mais

\footnotetext{
${ }^{14}$ DESCARTES, René. DESCARTES, René. Meditações sobre Filosofia Primeira. Trad. de Fausto Castilho.
} Campinas: UNICAMP, 2004, p. 81.

${ }^{15} \mathrm{O}$ sentido da distinção entre realidade objetiva e realidade formal nos pensadores modernos se contrapõe, de modo diametralmente oposto, à concepção contemporânea, de clara inspiração kantiana. Entre os contemporâneos, a realidade formal compete à interioridade da mente (anterior ao mundo externo), enquanto que a realidade objetiva diz respeito aos objetos exteriores ao intelecto, que lhe são posteriores. Já para os modernos é exatamente o contrário: a realidade objetiva se encontra no entendimento, sendo, portanto, a compreensão geométrica os objetos exteriores, enquanto a realidade formal corresponde às coisas externas, como as que são ofertadas pelas faculdades sensíveis, ganhando o status de objetos somente a partir do momento em que são refinadas pelo entendimento, tornando-se ideias. Sobre isso, Chaui nota que "Descartes [...] afirmou que o entendimento humano conhece imediata e intuitivamente as ideias enquanto realidades objetivas ou conceitos correspondentes a realidades formais ou coisas exteriores à mente" (CHAUI, 2006, p.57). A realidade objetiva compete à ideia e a realidade formal ao ideado. Uma ideia terá então tanto mais realidade objetiva (e, por conseguinte, mais graus de perfeição) conforme corresponda ao seu ideado (a coisa enquanto realidade formal), o que configura uma inversão da concepção contemporânea. Há nisso uma relação de causalidade eficiente, pois "na causalidade em que estão submetidas as próprias ideias e [que podem] oferecer como axioma que a realidade objetiva das ideias exige uma realidade formal que seja causa formal ou eminente delas" (CHAUI, 2006, p.343). Novamente uma inversão: não é a objetividade do entendimento que põe objetos que serão posteriormente corroborados por seus correlatos reais, mas é a realidade formal das coisas que leva ao engendramento de sua realidade objetiva. Neste trecho, apesar de lançar mão da objetividade a partir de sua acepção contemporânea (o objetivo para Merleau-Ponty será a coisa posta pelo pensamento; daí sua insistência em recuperar uma experiência anterior à consciência), Merleau-Ponty aqui a toma em sua concepção moderna, a fim de elucidar, de dentro do texto cartesiano, a superioridade ontológica do Deus infinito.

${ }^{16}$ DESCARTES, René. Meditações sobre Filosofia Primeira. Trad. de Fausto Castilho. Campinas: UNICAMP, 2004 , p. 81.

${ }^{17}$ Seguindo a distinção substancial do pensamento cartesiano, tudo o que é ideia só se refere ao pensamento, colocando-as, desde o princípio, como representações de coisas sensíveis e externas. Na Segunda Meditação, Descartes começa definindo a ideia a partir de seu campo próprio na mente: "Mas, que sou, então? Coisa pensante. Que é isto? A saber, coisa que duvida, que entende, que afirma, que nega, que quer, que não quer, que imagina também e que sente" (DESCARTES, 2004, p.51). As ideias serão o fruto desta atividade mental, os pensamentos que se seguirão aos estímulos corporais do exterior e que serão refinados em imagens, raciocínios e juízos. As sensações, que darão origem às ideias mais primitivas, confusas enquanto referidas apenas ao corpo, poderão se tornar verossímeis quando forem conferidas pelo pensamento. O mesmo se pode dizer da imaginação: seu conteúdo pode ser enganoso e fictício, mas, enquanto faculdade do pensamento, não há dúvida de que sua atividade seja real. Demonstra Descartes que "eu também sou o mesmo que imagina, pois, ainda que, segundo supus, nenhuma coisa imaginada seja verdadeira, a própria força de imaginar, todavia, existe deveras e faz parte de meu pensamento. Finalmente, eu sou o mesmo que sente e percebe coisas corporais [...]. Isto é o que em mim se chama propriamente sentir, o que, tomado assim, precisamente, nada mais é do que pensar" (DESCARTES, 2004, p.53). Por isso a teoria da verdade cartesiana se fiará correspondência da ideia com seu ideado, através dos graus de ser e de perfeição que

\begin{tabular}{|c|c|c|c|c|c|}
\hline intuitio & $\begin{array}{c}\text { ISSN } \\
1983-4012\end{array}$ & Porto Alegre & Vol.10 - N . .2 & $\begin{array}{c}\text { Dezembro } \\
2017\end{array}$ & p. 130-156 \\
\hline
\end{tabular}


semelhanças possuem com seus objetos (os ideados), mais essas ideias possuem graus de ser ou de perfeição, uma vez que a realidade formal ou o ser das coisas se distingue por seu grau de perfeição ou por sua realidade em si e, consequentemente, mais próximas estão da verdade. E qual é o grau de ser ou a realidade objetiva duma ideia inata como a dum Deus infinito e perfeito? "Por sua vez, aquela pela qual entendo um certo Deus supremo, eterno, infinito, imutável, onisciente, onipotente, criador de todas as coisas que estão fora dele, seguramente tem em si mais realidade objetiva do que as ideias pelas quais se mostram as substâncias finitas"18. Deus é provado apenas pela razão, isto é, sem recurso à experiência ou à imaginação; ou, em última instância, ao conhecimento revelado e às Escrituras ${ }^{19}$.

Descartes não apela apenas para a semelhança, mas também deduz Deus através da causalidade. Supondo que o grau de realidade objetiva ou de perfeição de um efeito depende duma causa mais perfeita e nunca o contrário, Descartes então define Deus como a causa primeira de todos os efeitos:

E, apesar de que talvez uma ideia possa acaso nascer de outra, não pode haver aqui, no entanto, progressus in infinitum e deve-se chegar por fim a uma primeira ideia, cuja causa seja como que arquétipo, no qual esteja contida formal e efetivamente toda a realidade ou perfeição que na ideia está contida apenas objetivamente ou por representação ${ }^{20}$.

se estabelecem entre ambos.

${ }^{18}$ DESCARTES, René. Meditações sobre Filosofia Primeira. Trad. de Fausto Castilho. Campinas: UNICAMP, 2004, p. 81.

${ }^{19}$ Merleau-Ponty lê Descartes a partir da interpretação de Gueroult, que é uma leitura a partir da ordem das razões e que se desenrola de maneira geométrica, em que o encadeamento das ideias se dá de maneira necessária. O Deus cartesiano é essencialmente dessacralizado: o caminho que conduz a Ele não é o da revelação ou da fé, mas o da razão e da lógica. Trata-se ainda de um Deus voluntarioso, mas cuja vontade não reflete a contingência: ela é designada por um ato racional e obedecendo a leis racionais que o fazem inteligível à mente humana, ainda que transcendente. Deus seria, a princípio, a origem tanto do valor objetivo quanto da verdade (pois é ontologicamente superior ao pensamento). Porém, como pensar uma origem comum, sendo os dois problemas distintos em essência? "Ocorre que a origem era postulada e não demonstrada, e o que se contestou foi não tanto se seria necessário, mas se seria suficiente destrinchar o problema da origem para resolver aquele do valor objetivo" (GUEROULT, 2016, p.204). Qual seja, apesar de seu empenho em provar a clareza e a distinção das ideias, Descartes ainda opera sob o signo da ambiguidade, a da essência implicada na existência: "a dúvida maléfica referese, no momento atual, a dois pontos capitais: 1) à existência das coisas fora de mim (essências ou existências); 2) à conformidade possível de minha ideia a tais coisas- no caso delas existirem. Ora, é evidente que não há representação possível de tais coisas se elas não existem" (GUEROULT, 2016, p.204). A clareza e a distinção não são tão facilmente discerníveis e, dos pontos de vista da ontologia e da epistemologia, faz-se necessário recorrer a uma ideia que conjugasse os atributos da infinitude, eternidade e perfeição: "Será preciso estabelecer que existe alguma coisa fora de mim e também que uma ideia em mim se refere necessariamente a essa coisa e me faz conhechla , isto é, que ela me apresenta uma cópia fiel da coisa" (GUEROULT, 2016, p.204). A única ideia capaz de reunir a máxima objetividade e a suprema verdade é Deus, que está fora do mundo e do pensamento. Assim, "a razão superior que será preciso descobrir deverá escapar a essa precariedade e a essa temporalidade, constituir uma substancialidade epistemológica que se sustente completamente por si mesma, oferecendo assim ao saber a inquebrantável fundação de rocha ou argila" (GUEROULT, 2016, p.185). Os caracteres de eternidade, infinitude e onipotência de Deus operam num nível epistemológico, perdendo o sentido teológico que lhes foi atribuído pela filosofia e pela cultura.

${ }^{20}$ DESCARTES, René. Meditações sobre Filosofia Primeira. Trad. de Fausto Castilho. Campinas: UNICAMP, 2004, p. 85.

\begin{tabular}{|c|c|c|c|c|c|}
\hline intuitio & $\begin{array}{c}\text { ISSN } \\
1983-4012\end{array}$ & Porto Alegre & Vol.10 - N .2 & $\begin{array}{c}\text { Dezembro } \\
2017\end{array}$ & p. 130-156 \\
\hline
\end{tabular}


Deus é perfeição, isto é, está no topo da escala ontológica. Ele valida as leis da Natureza porque sua vontade infinita, logo após criar o mundo contingente, decreta que as leis desse mundo (as leis mecânicas e eternas, matemática e geometricamente determináveis, que arranjam a Natureza, são necessárias). O Todo é então a chave que decifra o sentido disperso nas partes fragmentadas.

Por conta disso, a certeza do Cogito que decifra as leis da Natureza virá duma instância externa. O que interessa a Descartes é saber se a realidade objetiva das ideias corresponde à realidade formal dos ideados- tarefa impossível caso não se deduza (e se confirme) a veracidade e a perfeição do Deus infinito ${ }^{21}$ Enquanto imperar a hipótese do Deus enganador, a correspondência entre ideia e ideado, em todos os seus graus, não se consuma. Daí a necessidade de se provar Deus pelos efeitos ${ }^{22}$. Merleau-Ponty se mantém rente à interpretação de Gueroult: Descartes deve ser lido segundo a ordem das razões, sua filosofia tomada como "um bloco de certeza e em conformidade com a indivisibilidade da verdade, se ela se estabelece, assim como a matemática, por meio de um estrito encadeamento segundo a ordem das

\footnotetext{
${ }^{21} \mathrm{O}$ texto das Meditações, ao fundamentar a certeza e a veracidade das ideias, caminha em linha reta: parte da dúvida (necessidade dum novo conceito de verdade), atravessa a descoberta do Cogito (dedução da primeira certeza) e nela se conduz à primeira prova da existência de Deus (dedução do fundamento da verdade). O objetivo de Descartes é buscar uma primeira certeza que sirva de base para todo o conhecimento, construído apenas pelo intelecto. Tal é o movimento que anima as três primeiras Meditações, voltadas à fundamentação desta primeira certeza. É por isso que Descartes coloca o sujeito como uma coisa "imperfeita, incompleta e dependente de outra coisa, aspirando indefinidamente a coisas cada vez maiores e melhores" (DESCARTES, 2004, p.103). O próprio ato de pensar já presume a existência necessária de Deus e a verdade das ideias, de modo que conduz infalivelmente à dedução de que "aquele de quem dependo tem em si todas essas coisas maiores a que aspiro e cujas ideias encontro em mim, não de maneira indefinida e só em potência, mas real e infinitamente" (DESCARTES, 2004, p.103). Ora, quais eram então as suas intenções ao escrever as três primeiras meditações? Há no texto cartesiano uma preocupação em descrever e convidar o leitor (filósofo) a empreender a mesma jornada; não é um texto analítico, mas sintético, com um caráter preparatório para as três meditações seguintes, que já se situam no plano das ideias verdadeiras. Tornaremos a falar disso (com mais profundidade) em momento oportuno.

${ }^{22}$ A Quinta Meditação se propõe a examinar a verdade das coisas materiais pensadas pelo intelecto e acaba por formular uma segunda prova da existência de Deus, desta vez por uma outra via. Trata-se do movimento que se segue após todo o trajeto percorrido nas três primeiras Meditações: nelas, há a intenção explícita de se determinar a primeira certeza e o lugar da verdade (Cogito e intelecto), sendo que lá Deus é apontado como a causa da evidência dessa primeira certeza; já na Quinta Meditação, parte-se dos efeitos de Deus (as ideias claras e distintas) para se chegar a ele enquanto ideia diretriz. Um círculo é fechado: só se conhece a verdade conhecendo-se a suprema perfeição e infinitude de Deus, e Deus, quando conhecido, torna possível que se pense a verdade e a perfeição das ideias. A segunda prova da existência de Deus se dá então através da analítica de seus efeitos. Prosseguindo em sua argumentação, Descartes nota que "se só porque posso extrair de meu pensamento a ideia de alguma coisa segue-se que todas as coisas que percebo pertencerem clara e distintamente a essa coisa deveras lhe pertencem" (DESCARTES, 2004, p.137). As características essenciais de uma coisa, que diferem radicalmente de seus acidentes e modos, dela não podem ser alijadas, sob o risco de a contradizerem (seria um contrassenso, ou mesmo um exercício bizarro de imaginação, conceber um triângulo de dois ou quatro lados). Assim, sobre o que já se deduziu acerca de Deus, Descartes observa que "é certo que encontro em mim a sua ideia, isto é, a ideia de um ente sumamente perfeito, não menos do que em mim encontro a ideia de qualquer figura ou de qualquer número. [...] Por conseguinte, mesmo que não fosse verdadeiro tudo o que meditei nos últimos dias, a existência de Deus deveria estar em mim com pelo menos o mesmo grau de certeza" (DESCARTES, 2004, p.137). Sobre isso falaremos mais à frente, em momento oportuno.
}

\begin{tabular}{|c|c|c|c|c|c|}
\hline intuitio & $\begin{array}{c}\text { ISSN } \\
1983-4012\end{array}$ & Porto Alegre & Vol.10 - No.2 & $\begin{array}{c}\text { Dezembro } \\
2017\end{array}$ & p. 130-156 \\
\hline
\end{tabular}


Uma difícil aproximação: esboços da presença cartesiana no curso sobre a Natureza de Merleau-Ponty

razões"23. Tanto que o comentador destaca o caráter iniciativo das Meditações, sendo a dúvida o seu preâmbulo.

Como se trata duma leitura que é feita não a partir da ordem das matérias (o que conferiria à obra um caráter sintético), mas sim das razões (em que as teses primeiras tornam-se condição das seguintes, e essas segundas, por sua vez, são a demonstração ou confirmação das primeiras), o método de Gueroult é analítico, que é também a mesma maneira pela qual Merleau-Ponty aborda Descartes ao conceber e proferir seu curso. Parte-se, portanto, da desmontagem do complexo em busca de suas partes mais simples e gerais, que constituirão, aos olhos cartesianos, os entes ou coisas mais claras, certas e indubitáveis. As visões gueroultiana e merleau-pontyana partilham duma mesma conclusão: todo o projeto de Descartes culmina na construção dum sistema filosófico de saberes que orientam todas as ciências na obtenção da verdade em suas teses. Por conta disso, as Meditações se deixam guiar por três grandes eixos metafísicos: o fundamento da verdade, os limites da inteligência e o fundamento das ciências da natureza ${ }^{24}$. Para tanto, esses três eixos só podem ser movidos pela certeza; sem um estatuto que assegure a verdade para além da mera opinião ou da especulação desmesurada, só resta a tradição acumulada e retorquida ao longo do tempo e o "boca a boca" onde vicejam preconceitos e superstições, o que justamente Descartes quer combater.

Para tanto, como estamos na seara da análise, o primeiro procedimento a se adotar será o de duvidar de tudo quanto possa parecer digno de suspeita. Porém, não se trata de exercício cético: a dúvida deve ser metódica (instrumentalizada e controlada), universal (abarca todo o conhecimento) e radical (não pondera nem relativiza), mas também provisória (é meio para a obtenção das certezas, daí seu caráter instrumental; não é conclusão, nem constatação, tampouco condição de possibilidade do conhecimento).

Colocada em aplicação,

a Primeira Meditação indica o meio para alcançá-lo [o conhecimento]; a dúvida hiperbólica, que rejeita completamente tudo o que não pode ser tomado como certo. A realização dessa dúvida não consiste em censurar as diversas opiniões, mas em criticar o princípio sob o qual elas estão assentadas, o que implicará a ruína de todas as opiniões ${ }^{25}$.

Empresa no mínimo inusitada. Gueroult começa pelos pressupostos cartesianos expostos na Primeira Meditação: “os sentidos nos enganam. As percepções sensíveis talvez não passem de sonhos. Mas os sonhos só são imaginários porque combinam arbitrariamente elementos mais simples e mais gerais: olhos, mãos, cabeças, corpos, etc."26. Há aqui um trabalho de composição de imagens que em muito se assemelha ao delírio e às paisagens de sonho: neste arranjo se perdem as ideias inatas subjacentes

\footnotetext{
${ }^{23}$ GUEROULT, Martial. Descartes segundo a ordem das razões. Trad. de Érico Andrade et al. São Paulo: Discurso Editorial, 2016, p. 22.

${ }^{24}$ Cf. GUEROULT, Martial. Descartes segundo a ordem das razões. Trad. de Érico Andrade et al. São Paulo: Discurso Editorial, 2016, p. 28.

${ }^{25}$ Ibid., p. 39.

${ }^{26}$ Ibid., p. 40.
}

\begin{tabular}{|c|c|c|c|c|c|}
\hline intuitio & $\begin{array}{c}\text { ISSN } \\
1983-4012\end{array}$ & Porto Alegre & Vol.10-N N .2 & $\begin{array}{c}\text { Dezembro } \\
2017\end{array}$ & p. 130-156 \\
\hline
\end{tabular}


ao turbilhão de ideias adventícias e factícias. O trabalho cartesiano assume, portanto, uma tarefa de desvelamento, que é, a rigor, uma crítica.

Aceitando que "todas as ideias compostas são suspeitas [...] [e] todas as ideias indecomponíveis, ou naturezas simples, quer sejam intelectuais ou sensíveis, são necessariamente indubitáveis, porque elas não podem ser factícias"27, Gueroult se encaminha para a fundamentação do Cogito como primeira certeza. O comentador bem conhece esse caminho, sabe a quais resultados chegará, a partida e o destino não the são em nada desconhecidos, mas é o ínterim traçado entre esses dois pontos o que lhe interessa.

Estamos agora diante do puro ato de duvidar. É possível duvidar da dúvida? Caso se pudesse efetuar tal procedimento absurdo, teríamos de afastar tudo que nos parecesse composto no ato de pensar, descartando de pronto a imaginação, os sentidos, a vontade e, vá lá, o raciocínio. O elemento mais simples a que se chega é, justamente, a dúvida mesma. O próprio ato de pôr as coisas em dúvida envolve a sua condição de possibilidade, obtendo assim a primeira certeza (o pensamento) e o seu local de origem (o sujeito pensante). A fórmula do Cogito ergo sum (penso, logo existo; ou ainda eu penso, eu existo) ${ }^{28}$ é preenchida por esse estofo: "a impossibilidade de duvidar se funda nesse caso na natureza do ato mesmo de duvidar e na presença necessária nesse ato de sua condição sine qua non: o sujeito pensante. A certeza provém, então, unicamente do sujeito" ${ }^{\text {29 }}$.

Resta ainda dar conta do Gênio Maligno. O que fazer com essa invenção, tornada obsoleta pela constatação da primeira certeza? A ficção bem serviu enquanto recurso da dúvida metódica, e, como ferramenta, é deixada de lado assim que cumpre seu papel. Já que o sujeito é capaz de elaborar ideias claras e distintas, e sendo Deus a ideia mais verdadeira a que se pode chegar, Gueroult conclui que

A partir do momento em que conheço clara a distintamente está onipotência, concebo por uma única e mesma razão que ela me criou livremente tanto quanto criou livremente as verdades eternas, pois a onipotência divina é a autora necessária de todo o ser. Ademais, a onipotência de Deus não pode me enganar, nem querer me enganar, pois ela não pode ser autor do não $\operatorname{ser}^{30}$.

Em outras palavras, o pensamento necessita de algo que seja ontologicamente superior para fundamentar suas certezas:

A certeza da certeza que o caracterizava parece requerer, por sua vez, uma certeza de terceira potência, que a fixaria definitivamente. Dito de outro modo, se, como vimos, o grau de certeza é função do grau de simplicidade e absolutidade das razões, a deficiência que testemunha ainda a certeza do Cogito parece atestar que ele não constitui a razão

\footnotetext{
${ }^{27}$ GUEROULT, Martial. Descartes segundo a ordem das razões. Trad. de Érico Andrade et al. São Paulo: Discurso Editorial, 2016, p. 41.

${ }^{28}$ Essa tradução, diferente das que foram consagradas pelos escritos cartesianos em português, é de Fausto Castilho, vertida diretamente do original latino. É ela que adotamos em todo o nosso trabalho.

${ }^{29}$ Ibid., p. 47.

${ }^{30}$ Ibid., p. 52.
}

\begin{tabular}{|c|c|l|l|c|c|}
\hline intuitio & $\begin{array}{c}\text { ISSN } \\
1983-4012\end{array}$ & Porto Alegre & Vol.10- No.2 & $\begin{array}{c}\text { Dezembro } \\
2017\end{array}$ & p. 130-156 \\
\hline
\end{tabular}


Uma difícil aproximação: esboços da presença cartesiana no curso sobre a Natureza de Merleau-Ponty

mais simples e a mais absoluta, e que ele deve, por sua vez, referir-se a uma razão mais alta $^{31}$.

O Deus infinito não apenas organiza as leis da Natureza, mas as torna inteligíveis à razão humana e dota o pensamento da capacidade de decifrá-las e compreendê-las ${ }^{32}$. Tal conclusão Merleau-Ponty toma emprestada de Gueroult, depois de guiar toda a sua reflexão segundo a ordem das razões e não das matérias: é uma leitura mediada por outro trajeto argumentativo, no caso do de Gueroult, que autoriza Merleau-Ponty a desenhar a figura divina que ele persegue e critica desde o início.

Este é o recorte feito por Descartes neste primeiro movimento do curso. Após esse movimento do texto, Merleau-Ponty expõe os pontos de vista de Leibniz e Malebranche sobre a infinitude de Deus. Merleau-Ponty os insere no curso, levando-se em conta o estudo das variações histórias do sentido de Natureza, por um motivo pedagógico: para mostrar aos alunos como foi a recepção e a repercussão do pensamento cartesiano entre seus contemporâneos. Mas o que a princípio seria apenas uma exposição didática acaba por constatar algumas lacunas no argumento cartesiano, que levarão Merleau-Ponty a investigar a possibilidade duma segunda inspiração cartesiana sobre a Natureza.

Leibniz lê o Deus cartesiano com um viés fatalista ${ }^{33}$ : o Deus de Descartes poderia criar a Natureza de outra maneira, mas acaba apenas por criá-la segundo as leis necessárias da matéria, não sendo ela, portanto, a melhor dentre as alternativas possíveis. Leibniz então defenderia a ideia de um Deus que, dentre várias escolhas possíveis, optaria por um mundo dotado da máxima plenitude; ora, para Descartes o que substituiria essa escolha seria uma espécie de "mecânica divina", tomando-se o termo "mecânica" em sentido lato, isto é, como conjunto de leis invariáveis e universalmente aplicáveis. Desta maneira, "o esforço para distinguir Deus e a matéria graças ao abismo do entendimento infinito de Deus e de seus possíveis é então nuançado pela presença de razões que justificam a realização da escolha, que são intrínsecas ao Mundo em questão, e não desejadas por Deus" (N, p.28).

Já Malebranche, ao invés de criticar, tenta defender Descartes, embora seus argumentos ainda não compreendam claramente as consequências do infinito sobre o finito ${ }^{34}$. Sobre a exterioridade de Deus e da

${ }^{31}$ GUEROULT, Martial. Descartes segundo a ordem das razões. Trad. de Érico Andrade et al. São Paulo: Discurso Editorial, 2016, p. 183.

${ }^{32}$ A prova da existência de Deus conta como primeira prova da verdade das ideias das coisas. "Verdade e realidade são sinônimos" (GUEROULT, 2016, p.214). Conclui-se, portanto, que a investigação acerca do valor objetivo das ideias e a prova da existência de Deus se interpenetram e articulam um único campo de investigação: "a prova da existência de Deus aparece como o meio em relação à solução do problema do valor objetivo das ideias, que é o fim; por outro lado, a investigação que visa encontrar a solução do problema do valor objetivo das ideias aparece como o meio em relação à demonstração da existência de Deus, que é o fim" (GUEROULT, 2016, p.214)

33 "Seu Deus [o de Descartes] faz tudo o que é factível e passa, seguindo uma ordem necessária e fatal, por todas as combinações possíveis: mas para tanto bastaria apenas a necessidade da matéria, melhor dizendo, seu Deus não é nada senão esta necessidade, ou este princípio da necessidade agindo na matéria como pode" (LEIBNIZ apud MERLEAU-PONTY, N, p.28.

34 "Descartes sabia que para bem compreender a natureza das coisas era preciso considerá-las em sua origem e nascimento, que era necessário sempre começar por aquelas que são as mais simples, e ir primeiramente ao princípio.

\begin{tabular}{|c|c|c|c|c|c|}
\hline intuitio & $\begin{array}{c}\text { ISSN } \\
1983-4012\end{array}$ & Porto Alegre & Vol.10- N.2 & $\begin{array}{c}\text { Dezembro } \\
2017\end{array}$ & p. 130-156 \\
\hline
\end{tabular}


Uma difícil aproximação: esboços da presença cartesiana no curso sobre a Natureza de Merleau-Ponty

Natureza, "Malebranche insiste no fato de que as leis da Natureza asseguram a manutenção do Mundo. Isso prova que as mesmas leis nos puderam conduzir a esse Mundo. Dito de outra maneira, se houvesse outras leis originalmente, o Mundo seria diferente" (N, p.29). Há em Malebranche um equívoco comum a Leibniz: se, segundo Merleau-Ponty, o primeiro tomava Deus como uma racionalidade capaz de criar infinitos mundos e de escolher o melhor dentre eles, em Malebranche há a tese duma conservação contínua do ato criador: Deus lançaria mão de algumas ideias simples e ideais do mundo, que se atualizariam conforme a criação fosse renovada.

Entre os comentários de Leibniz e Malebranche subjaz uma mistura de contingência (Deus é uma infinita potência de escolher, ou seja, racionalidade onipotente) e necessidade (a Natureza criada por Deus não poderia ser de outra maneira). Os caminhos são diferentes, mas o equívoco é o mesmo: em ambos, haveria uma interioridade operante entre as partes da Natureza.

Ora, para Descartes a Natureza não possui interior; impossível falar duma racionalidade operante ou dum arranjo racional entre suas partes, pois são todas externas a si próprias, relacionando-se apenas através da causalidade. Como infinito, Deus a encara como um objeto externo, dispondo dela qual um relojoeiro com seu invento. É essa exterioridade que escapou a Leibniz e Malebranche.

Desta maneira, sendo um finito derivado do infinito, a Natureza se apresenta como um ser pleno, todo formado por determinações, evidente por si mesmo e totalmente previsível e calculável a partir das relações de causalidade entre suas partes. Sobre a questão da plenitude do ser da Natureza, Barbaras argumenta que

porque é balanceada com um nada possível, a natureza é concebida como procedente um ser infinito: só pode emergir do nada por sua plenitude de ser. Ora, em virtude da identidade do entendimento e da vontade de Deus, a natureza é de ponta a ponta o que é para o entendimento, ou seja, possibilidade realizada ${ }^{35}$.

O infinito se comporta como a consciência pensante, para o qual a Natureza seria seu objeto. Sendo assim, nada há nos seres que os impulsione para fora ou para além de si. Merleau-Ponty chega a propor uma "inércia ôntica da essência", tomando-se o sentido lato de inércia na física, isto é, um movimento que se reduz a si mesmo, sem um télos ou uma arché que o impulsionem. Assim, o autor do curso sobre a Natureza constata o "surgimento dum ser que chamamos de Mundo e que não pode não ser um ser verdadeiro. Logo, a ideia de Natureza resulta da prioridade dada ao infinito sobre o finito" (N, p.31). A Natureza que surge dessa concepção é o que é, não podendo ser outra, e é tal como é, sem

[...] Ele sabia que as leis da Natureza, pelas quais Deus conserva todas as suas obras na ordem e na situação em que subsistem, são as mesmas leis que aquelas pelas quais pôde formá-las e arranjá-las. [...] Se todo o universo permanece na ordem através da qual nós o vemos, é porque as leis dos movimentos que a conservam nesta ordem foram capazes de a estabelecer. E se Deus as tivesse colocado numa ordem diferente dessa, em que se colocam determinadas pelas leis do movimento, todas as coisas se inverteriam e se colocariam, pela força dessas leis, na ordem em que as vemos no presente" (MALEBRANCHE apud MERLEAU-PONTY, N, p.29)

${ }^{35}$ BARBARAS, Renaud. De l'être du phénomène: sur l'ontologie de Merleau-Ponty. Grenoble: Éditions Jérôme Millon, 2001, p. 53.

\begin{tabular}{|c|c|l|l|c|c|}
\hline intuitio & $\begin{array}{c}\text { ISSN } \\
1983-4012\end{array}$ & Porto Alegre & Vol.10- $\mathrm{N}^{\circ} .2$ & $\begin{array}{c}\text { Dezembro } \\
2017\end{array}$ & p. 130-156 \\
\hline
\end{tabular}


comportar o não ser em seu seio. "Daí a ausência de grau no Ser. A Natureza não comporta fraqueza alguma em seu tecido" (N, p.31)

Sendo assim, o que resta? A conclusão de Merleau-Ponty é a de que "a ideia ingênua dum mundo primordial, anterior à fabricação humana, é exprimida pelos cartesianos na ideia duma produtividade infinita da Natureza, que é tudo o que pode ser, pela ideia duma permanência da Natureza" (N, p.33). A Natureza é então objeto para uma consciência, mais especificamente, para a consciência de Deus; o finito portanto se subordina ao infinito. Em sua primeira inspiração, Descartes reflete o espírito da época e institui uma linha de pensamento que se tornará paradigmática: enquanto objeto e causalidade, a Natureza pode ser compreendida e manipulada pela consciência; sua produtividade exprime a produtividade do infinito que a maneja. Neste primeiro instante, a concepção cartesiana que Merleau-Ponty recorta é oposta à ontologia da Natureza que pretende defender em suas últimas obras; há, portanto, uma primeira apropriação crítica.

\section{A realidade do corpo: a segunda inspiração cartesiana}

Até então, Merleau-Ponty concebe a Natureza como dotada de propriedades intrínsecas que derivam do infinito; nesta concepção, há a proeminência do naturante sobre o naturado, naturante este que se torna a origem e o curador de suas leis primordiais. A relação do infinito com o finito é como a do entendimento com o objeto; daí resulta que o mundo não tenha interior, sendo uma totalidade fechada guiada por leis de causalidade.

Vimos, portanto, que o infinito garante a permanência da Natureza. Porém, a Natureza que emerge dessa conclusão é obtida não por uma experiência direta das coisas do mundo, mas pela ascese das primeiras Meditações. Trata-se de um mundo descoberto apenas pelo pensamento; afinal, a ideia de infinitude e de perfeição só pode ser obtida e concebida na pureza do entendimento, pois é nos sentidos que residem a confusão e a falsidade, incompatíveis com a clareza e a verdade que caracterizam Deus.

Há em Descartes uma ruptura que se prolongará por toda a sua obra, para a qual jamais é buscada uma solução: um abismo separa a razão (iluminada pela luz natural) e a experiência (movida pela

\footnotetext{
${ }^{36} \mathrm{O}$ mesmo se poderá dizer do corpo vivente. Engenho composto por peças como ossos, nervos, músculos, sangue, artérias e vísceras, o corpo necessita da direção da vontade e do espírito, no caso, da consciência, o seu organizador, que se comporta, guardadas as devidas proporções, como Deus perante a Natureza: "a orientação do corpo vivente é devida ao pensamento do organizador, e em nada responde à orientação dos tecidos. É porque Descartes elimina todo predicado de valor, e da ideia de Natureza conserva apenas a ideia dum agenciamento interno dos órgãos. A Natureza é o que tem propriedades intrínsecas constitutivas, a propósito das quais tudo o que o observador pode introduzir é exterior" (N, p.33). É por causa disso, por exemplo, e levando em conta que a união entre corpo e alma é confusa, que o hidrópico sente sede através da sensação de secura na garganta, mesmo com sua consciência e sua vontade sabendo que a ingestão de água é prejudicial.
}

\begin{tabular}{|c|c|c|c|c|c|}
\hline intuitio & $\begin{array}{c}\text { ISSN } \\
1983-4012\end{array}$ & Porto Alegre & Vol.10-N .2 & $\begin{array}{c}\text { Dezembro } \\
2017\end{array}$ & p. 130-156 \\
\hline
\end{tabular}


Uma difícil aproximação: esboços da presença cartesiana no curso sobre a Natureza de Merleau-Ponty

inclinação natural). É por isso que, acompanhando o movimento do texto cartesiano, Merleau-Ponty identificará uma segunda inspiração, que, contudo, não confirmará nem completará as primeiras conclusões; ao contrário, ela introduzirá uma faceta do problema da Natureza até então ignorada pela primeira inspiração. Em outras palavras, a Sexta Meditação e o Tratado das Paixões, ao se pautarem pela união substancial, darão um lugar ao corpo que seria inadmissível (ou até mesmo contraditório, dependendo da leitura que delas se fará) nas cinco primeiras meditações. A figura do homem como composto substancial, ideia confusa desde o princípio, impele o pensamento cartesiano numa outra direção, marcando um ponto de inflexão.

Quando separados pela luz natural, pensamento e extensão surgem como substâncias distintas. Porém, na facticidade do corpo e na experiência, encontram-se misturados numa união confusa ${ }^{37}$. Merleau-Ponty indica então uma segunda inspiração motivada agora pela sensibilidade, que, uma vez confirmada a veracidade divina, não mais é enganosa.

O texto cartesiano opera então em regime de ambivalência: Merleau-Ponty observa que, mesmo que o mundo seja acessível apenas ao entendimento puro, como o queria a primeira inspiração, "ao lado deste acesso ao mundo possível pela ideia de extensão inteligível ${ }^{38}$, Descartes mantém a originalidade dum mundo efetivamente real, duma extensão realizada" (N, p.33). Há, a rigor, duas filosofias da

\footnotetext{
${ }^{37}$ Como se lê na Sexta Meditação: "A natureza também me ensina, por essas sensações de dor, fome, sede etc., que não estou presente a meu corpo como o marinheiro ao navio. Estou a ele ligado de modo muito estreito e como que misturado com ele, a ponto de com ele compor uma só coisa. [...] Pois essas sensações de sede, fome, dor etc., não são mais do que modos de pensamentos confusos, resultantes da união e como que mistura da mente com o corpo" (DESCARTES, 2004, p.175)

${ }^{38}$ Para Malebranche é impossível falar do objeto mesmo em sua realidade própria: como a toda modificação da extensão corresponderá uma modificação do pensamento, o que se terá é a experiência das ideias das coisas. Sobre isso, pontua Teodoro, personagem dos Entretiens, que "como os homens tomam por nada as ideias que têm das coisas, dão ao mundo criado muito mais realidade do que ela própria tem" (MALEBRANCHE, 1991, p.36). Logo, as ideias não correspondem exatamente aos objetos com os quais se correlacionam, o que nos leva à conclusão de que "as ideias têm uma existência eterna e necessária, e que o mundo corporal apenas existe porque Deus teve o prazer de criá-lo. Assim, para contemplar o mundo inteligível, faz-se necessário consultar a Razão que encerra as ideias inteligíveis, eternas e necessárias, o arquétipo do mundo visível" (MALEBRANCHE, 1991, p.36-37). O termo "arquétipo" se relaciona à perfeição, isto é, a Deus. Esta é a base do ocasionalismo que permeia a obra de Malebranche: só Deus pode revelar as ideias perfeitas, necessárias e eternas, enquanto que os objetos dos sentidos são apenas causas ocasionais das modificações. O que definirá então a extensão inteligível? Teodoro alertará Aristo de que "as dimensões que vejo são imutáveis, eternas, necessárias. Essas dimensões inteligíveis que me representam todos os espaços não ocupam lugar algum" (MALEBRANCHE, 1991, p.39). Assim, a ideia das relações de distância implicadas na extensão será ontologicamente superior à percepção das formas das coisas extensas, que para Malebranche se constituem de sensações mutáveis, corruptíveis e contingentes, ou seja, causas ocasionais. Sobre elas, conclui Malebranche que "se são eternas, imutáveis, necessárias, divinas, em uma palavra entendo a extensão inteligível da qual são formadas, seguramente serão mais consideráveis que esta matéria ineficaz e por si mesma absolutamente invisível" (MALEBRANCHE, 1991, p.40). Ao questionar a postura malebranchiana, Merleau-Ponty entenderá a extensão inteligível como uma mediação ideal interposta entre o sujeito e o mundo sensível. O que é refutado na segunda inspiração cartesiana, que defende que a percepção das coisas implica em sua realidade mesma, de maneira imediata, sem a necessidade de apelar aos arquétipos de Deus. A leitura de Merleau-Ponty neste curso manterá uma visão crítica da filosofia de Malebranche, colocando-o como opositor de Descartes.
}

\begin{tabular}{|c|c|c|c|c|c|}
\hline intuitio & $\begin{array}{c}\text { ISSN } \\
1983-4012\end{array}$ & Porto Alegre & Vol.10 - No.2 & $\begin{array}{c}\text { Dezembro } \\
2017\end{array}$ & p. 130-156 \\
\hline
\end{tabular}


Natureza agora, pois "quando pensamos o espaço, pensamos uma unidade espiritual [...]; quando o vemos, encontramo-nos em face de partes justapostas" (N, p.33-34). Instala-se um conflito entre um idealismo que se pretende absoluto e um realismo a princípio claudicante, no interior duma filosofia que persegue a clareza e a distinção e que se quer ver livre dos erros e imprecisões.

Conflito que expõe o reverso da primeira inspiração e as limitações do entendimento, que exprime apenas uma face da Natureza:

Certamente, o mecanismo cartesiano, no sentido estreito de explicação do mundo pelas máquinas simples, não tem futuro científico. Mas é interessante na medida em que traduz uma resistência à idealização do mundo. Não estamos em relação com correlatos do pensamento, mas com realidades $(\mathrm{N}, \mathrm{p} .34)$

O homem percebe e lida com coisas reais, seu corpo está em situação e suas sensações não são enganosas; trata-se duma experiência imediata que não precisa da intermediação do infinito. A primeira certeza do composto humano é a sensação de que tem um corpo vivo, e não de que seu entendimento é operante (não é à toa que, mesmo elaborando a hipótese o Gênio Maligno, Descartes parta dos sentidos, mesmo os negando).

A segunda inspiração pinçada por Merleau-Ponty insere um problema que não foi vislumbrado na primeira: a presença do homem, que se relaciona diretamente à questão da existência. Trata-se dum problema maior e mais amplo do que a infinitude de Deus, pois "há dois modos de compreender o homem, uma dupla natureza do homem: minha natureza no sentido amplo, como sendo o entendimento puro e tudo o que ele concebe; e minha natureza em sentido restrito, no sentido de composto alma-corpo (N, p.34).

Para Merleau-Ponty, não haverá passagem da primeira para a segunda inspiração: uma ruptura separará as duas perspectivas. Ruptura esta que demarca dois movimentos distintos nas Meditações: as primeiras três serão escritas sob a inspiração da luz natural, enquanto que as outras que se seguem serão guiadas pela inclinação natural. Até então, o homem era apenas um ente dotado de razão, que com ela deduzia o Infinito do qual derivava e no qual caucionava as leis inatas e eternas de seus raciocínios. Porém, esta reviravolta coloca o corpo em cena, mais precisamente um corpo que não é autômato formado por partes justapostas, mas que se comporta como o corpo encarnado do qual fala Merleau-Ponty.

O que implica, evidentemente, numa revisão de seu estatuto filosófico tal qual vinha sendo fundamentado nas formulações da luz natural: "Esse corpo que chamo de "meu" reclama um novo tipo de espaço que não é mais partes extra partes, nem extensão espiritual como um quadro: eu sou meu corpo. Qualquer que seja a natureza exterior, encontra-se ao menos no nível do homem uma natureza que não se apresenta com o caráter de objeto, que é para nós" (N, pp. 34-35).

A imagem de Descartes que emerge da apropriação crítica de Merleau-Ponty é, pois, a dum pensador contraditório, que defende um conjunto de teses para logo em seguida negá-las. Trata-se de tarefa irreconciliável: como alinhar a soberania do entendimento puro com a experiência imediata do

\begin{tabular}{|c|c|l|l|c|c|}
\hline intuitio & $\begin{array}{c}\text { ISSN } \\
1983-4012\end{array}$ & Porto Alegre & Vol.10- No.2 & $\begin{array}{c}\text { Dezembro } \\
2017\end{array}$ & p. 130-156 \\
\hline
\end{tabular}


corpo próprio? E como compreender essa ruptura (no sentido duma separação radical entre as duas teses), que também podemos tomar como reviravolta (posto que há uma inversão completa de perspectivas) no âmbito dum autor que, desde os primórdios de seu projeto filosófico, colocava-se como defensor dum discurso rigoroso e preciso, duma filosofia que se equipararia à ciência?

Relembremos: a clareza e a distinção se observam quando pensamento e extensão são tomados separadamente, no momento em que a luz natural é expurgada de todas as incertezas. Essa é a culminação do trajeto da dúvida metódica, que parte duma experiência confusa, em que os sentidos são causa de enganos e falsidade. Ora, para Descartes interessam apenas os frutos da razão já devidamente refinada pelo método; desde o início, seu ponto de partida é a confusão e a obscuridade. Porém, esta experiência confusa não é sanada pela luz natural, pois tudo o que razão produzirá de certo e verdadeiro virá após a prova do Cogito e da existência de Deus. Não há em Descartes uma preocupação em reformar ou emendar a experiência confusa inicial. Por conta disso, a união entre alma e corpo, mesmo sendo real e comprovada pela própria existência do sujeito, permanecerá confusa e obscura, sem um conceito ou definição.

Segundo Merleau-Ponty, Descartes fomenta uma grande dificuldade no interior de seu texto pois se esforça em admitir a segunda ordem de relações [a inclinação natural], sem renunciar à primeira ordem [da luz natural]. Coloca o corpo como exterioridade em relação a todo outro corpo, e como diferente de todos os outros corpos. A alma e o corpo tornam-se um para o outro meio e fim. Por esse entrelaçamento de finalidade relações de novo tipo se estabelecem no corpo. A unidade do corpo humano é diferente da do corpo [extenso] (N, p. 37)

A leitura de Merleau-Ponty traz a lume o rigor cartesiano- de manter a ordem das razões mesmo com o risco de se embrenhar em contradições. Ele recorrerá ao comentário de Gueroult para esclarecer os problemas internos do texto cartesiano. O comentador pautará seu argumento pela noção de um "excedente" (surplus) presente em todas as ideias elaboradas pelo entendimento, mesmo nas claras e distintas. O que faz com que clareza e obscuridade, ou verdade ou falsidade, ou ainda distinção e confusão, estejam atreladas. Sobre esse comentário notará Merleau-Ponty que "a luz natural nos ensina evidências indubitáveis. Tudo o que as ideias claras e distintas nos ensinam pertence ao ser; mas resta, em nossas ideias, um excedente. Esse excedente é tão somente um desmentido a respeito das ideias claras, pois pode ser pensado pelo entendimento" (N, p.35). A ideia de que haja um elemento inacessível ao entendimento em todas as suas operações, nos conceitos que elabora, nas noções que determina e mesmo nas ideias que obtêm, e que tal elemento, ainda que obscuro e indeterminado, é verdadeiro (porque a verdade é intrínseca a Deus) introduz o indefinido ${ }^{39}$, que se comporta tal qual uma mancha em meio ao infinito, da mesma maneira que o entendimento finito do homem se contrapõe à vontade eterna de Deus.

${ }^{39} \mathrm{O}$ indefinido surge numa carta de Descartes a Chanut datada de 6 de junho de 1647 . O texto do curso sobre a Natureza transcreve o seguinte trecho: "Para dizer que uma coisa é infinita, deve-se ter alguma razão que a faça conhecer como tal, que se pode ter apenas de Deus; mas para dizer que é indefinida, basta não ter razão alguma pela

\begin{tabular}{|c|c|c|c|c|c|}
\hline intuitio & $\begin{array}{c}\text { ISSN } \\
1983-4012\end{array}$ & Porto Alegre & Vol.10- No.2 & $\begin{array}{c}\text { Dezembro } \\
2017\end{array}$ & p. 130-156 \\
\hline
\end{tabular}


Uma difícil aproximação: esboços da presença cartesiana no curso sobre a Natureza de Merleau-Ponty

Porém, conceber o indefinido significaria despedaçar o estatuto da verdade sob o qual se assenta a filosofia cartesiana, pois, como observa Merleau-Ponty, "enquanto se afirmava que não podia ser verdadeiro aquilo que compreendo, diz-se agora que são verdadeiras as coisas que não posso compreender" (N, p.35)? Vejamos o que diz Gueroult.

A leitura de Guéroult que interessa a Merleau-Ponty nesta altura do curso é a que investiga o que o comentador denomina o nexus rationum da Sexta Meditação, isto é, a costura entre as duas perspectivas tecidas ao longo desta meditação e como elas se articulam a fim de provar a existência das coisas materiais. Gueroult lê a Sexta Meditação a partir de dois movimentos, que refletem a oposição entre a luz e a inclinação naturais. $\mathrm{O}$ primeiro movimento diz respeito à fundamentação das ciências, especialmente da física, medicina e psicologia, reportando-se à faculdade da inteligência; já o segundo movimento se ocupa da crítica dos limites da razão e das ideias, apoiando-se sobre o sentimento ou a faculdade dos sentidos para determinado valor objetivo das ideias sensíveis ${ }^{40}$. O nexus rationum seria a resposta para a mesma questão procurada por Descartes e Merleau-Ponty, e é por isso que o comentário de Guéroult desempenha um papel crucial no desenvolvimento do curso.

Ora, as duas perspectivas abertas pela leitura guéroultiana cavam dois campos distintos do saber, nos quais o entendimento se aplicará de maneiras diversas. Não é à toa que Merleau-Ponty recorre a um estudioso conhecido pelo racionalismo rigoroso em se ater à ordem das razões internas do texto. Não se trata, portanto, de identificar e recortar uma nesga de obscuridade no entendimento, como um erro ou falha que lhe seriam inerentes, mas de compreender o seu campo de aplicação e o modo como opera. Considerando-se que "o entendimento tem o poder de me elevar dessas variedades qualitativas imediatamente percebidas às variedades geométricas, desconhecidas da ideia sensível" ${ }^{\text {,1 }}$, podemos tomar o seguinte exemplo para ilustrar a operação do entendimento: o Sol percebido pela visão, disforme e menor que a Terra, imagem perceptiva, é ponto de partida para a determinação do Sol geométrico, isto é, da ideia depurada pela razão, que é o verdadeiro Sol com formato circular e dimensões maiores que as do planeta. Desta maneira, "se pressente que o mesmo processo intelectual desvelará simultaneamente a verdade do sentido em sua região (as propriedades de 'minha natureza' no sentido estrito) e a verdade do entendimento na sua (as propriedades reais das coisas)" ${ }^{, 42}$. A ideia de dois campos e duas aplicações diferentes descarta a possibilidade duma ruptura entre as ordens da luz e da inclinação naturais.

qual se possa provar que possui limites...não possuindo nenhuma razão para provar, e mesmo só podendo conceber que o mundo tenha limites, eu o nomeio indefinido. Mas não posso por isso negar que aí talvez não haja alguns limites que são conhecidos de Deus, embora me sejam incompreensíveis: é porque não digo absolutamente que ele é infinito. (DESCARTES apud MERLEAU-PONTY, N, p.35, grifos do autor).

${ }^{40}$ Cf. GUEROULT, Martial. Descartes segundo a ordem das razões. Trad. de Érico Andrade et al. São Paulo:

Discurso Editorial, 2016, pp. 445-461.

${ }^{41}$ GUEROULT, Martial. Descartes segundo a ordem das razões. Trad. de Érico Andrade et al. São Paulo: Discurso Editorial, 2016, p. 451.

${ }^{42}$ Ibid., p. 451.

\begin{tabular}{|c|c|c|c|c|c|}
\hline intuitio & $\begin{array}{c}\text { ISSN } \\
1983-4012\end{array}$ & Porto Alegre & Vol.10- $\mathrm{N}^{\circ} .2$ & $\begin{array}{c}\text { Dezembro } \\
2017\end{array}$ & p. 130-156 \\
\hline
\end{tabular}


Uma difícil aproximação: esboços da presença cartesiana no curso sobre a Natureza de Merleau-Ponty

Mais do que isso, o nexus rationum vislumbrado por Guéroult evidencia uma passagem da inteligência ao sentimento: a luz natural, através de suas diretrizes racionais, deduz a possibilidade de coisas materiais, enquanto que o sentimento, pelo contato imediato, obtém a certeza de que elas existem, comprovando seu valor objetivo $^{43}$. A imagem do pensador contraditório que surgia numa primeira leitura vai aos poucos rachando e ruindo.

Como então entender a presença do indefinido em meio ao infinito? Como dar conta dessa questão sem recorrer ao argumento da obscuridade?

Não nos esqueçamos de que o homem é finito, ser criado por Deus, sendo, portanto, dotado duma vontade e duma razão limitadas. Já a vontade de Deus, que é infinita e onipotente, pode criar verdades que estão além do entendimento humano, das quais o homem compreende apenas a possibilidade, sem delas ter a certeza. Há, portanto, uma situação que se limita apenas à região da inteligência, sem atingir a do sentimento: "daí nasce a distinção entre o infinito é o indefinido: no primeiro caso, percebo clara e distintamente que não pode haver fim [para o entendimento; no segundo caso, não concebo clara e distintamente como poderia haver um, sem tampouco conceber clara e distintamente que é necessário que não haja"44. Não há obscuridade, mas um efeito da diferença de natureza entre o homem e Deus.

Como Deus não pode criar o nada nem a negação, em suma "Deus, por sua onipotência, pode tudo fazer em princípio- mesmo o que julgamos como positivamente impossível-, desde que isso não repugne a sua própria onipotência, isto é, que não se trate da impossibilidade absoluta" ${ }^{\text {"45 }}$. Sendo assim, a experiência do indefinido é própria da finitude intrínseca do homem, para a qual Deus é o excedente máximo. Merleau-Ponty explora a leitura guéroultiana porque ele próprio se sente um seguidor do autor da ordem das razões ao encarar a filosofia de Descartes: as respostas se encontram no próprio autor, na urdidura dos argumentos e teses que se encadeiam no corpo do texto, sem a necessidade de recorrer a um elemento exterior. Respostas essas que excluem quaisquer contradições ou imprecisões que se poderiam esboçar.

Retornemos à leitura cartesiana. A verdade das coisas, a certeza do mundo e a clareza dos pensamentos só podem ser conhecidas através da prova da existência de Deus. É essa primeira certeza num Deus infinito que tornará possível, através da refutação da hipótese do Gênio Maligno, encontrar a verdade do pensamento e do mundo em que o sujeito está entranhado. Sendo assim, inspirando-se nos argumentos de Gueroult, Merleau-Ponty tomará o Deus cartesiano como intermediário nas relações entre sujeito e mundo, o que coloca, evidentemente, a verdade do mundo como uma verdade mediata.

\footnotetext{
${ }^{43}$ Cf. GUEROULT, Martial. Descartes segundo a ordem das razões. Trad. de Érico Andrade et al. São Paulo: Discurso Editorial, 2016, p. 460.

${ }^{44}$ GUEROULT, Martial. Descartes segundo a ordem das razões. Trad. de Érico Andrade et al. São Paulo: Discurso Editorial, 2016, p. 479-480.

${ }^{45}$ Ibid., p. 82.
}

\begin{tabular}{|c|c|c|c|c|c|}
\hline intuitio & $\begin{array}{c}\text { ISSN } \\
1983-4012\end{array}$ & Porto Alegre & Vol.10- $\mathrm{N}^{\circ} .2$ & $\begin{array}{c}\text { Dezembro } \\
2017\end{array}$ & p. 130-156 \\
\hline
\end{tabular}


O autor do curso considera que em Descartes "há, antes de tudo, duas zonas de verdade, a zona do verdadeiro absoluto e a zona do que não é falso e que, sendo não falso, pode ser afirmado verdadeiro" (N, p.36). Essas duas regiões são a inteligência (no caso de Deus) e o sentimento (no caso do homem). Na ordem das razões preconizada por Gueroult, a instituição da inteligência pela dedução da infinitude de Deus permite que, após se fiar numa primeira certeza indubitável, se passe ao domínio das verdades indefinidas do mundo. Como Deus é perfeito, a ele é impossível criar o falso, o erro e o Nada, todos frutos da imperfeição.

Assim, aponta Merleau-Ponty, para dissolver uma suposta inconsistência que existiria no estatuto cartesiano da verdade e para traçar uma ligação entre as duas inspirações que orientam a primeira parte do curso, que "o único erro consiste em crer que elas [a luz natural e a inclinação natural] se aplicam a um mesmo domínio, a uma mesma região: em Descartes, é o mesmo erro sofisticar (sic) o sentimento pela inteligência e a inteligência pelo sentimento" (N, p.36).

Apesar do argumento dos dois domínios aparentemente resolver o impasse, a confusão se mantém; a união entre a alma e o corpo não é resolvida: "é difícil conceber a alma e o corpo como uma só e mesma coisa, ao mesmo tempo que pensá-los como coisas distintas" (N, p.36). A mistura é uma contaminação de um pelo outro, para usarmos os termos de Merleau-Ponty, que permanece existente mesmo após o trajeto racional das Meditações.

Notemos atentamente: há uma grande diferença entre o corpo humano e o corpo animal, o que é atestado em vários escritos de Descartes. O animal se comporta como um mecanismo, pura extensão, ao passo que no humano se acrescenta o pensamento, que dota esse mecanismo duma finalidade (o humano, portanto, é o domínio da teleologia, como já adiantou Merleau-Ponty no início do curso). A alma se apresenta apenas no corpo humano. Portanto, o homem é caracterizado pela finalidade, que não existe no animal, um autômato. O que leva a concluir que "a alma e o corpo tornam-se um para o outro meio e fim. Por esse entrelaçamento de finalidade relações dum novo tipo se estabelecem no corpo. A unidade do corpo humano é diferente da do corpo [extenso]" (N, p.37). O corpo humano é marcado pela indivisibilidade, que é uma característica típica da alma.

Assim, Merleau-Ponty encontra uma dificuldade que não é resolvida em toda a obra de Descartes:

O que Descartes diz do corpo humano parece então marcar uma ruptura com sua concepção de Natureza. Daí a necessidade na qual se encontra Descartes, de conferir à matéria do corpo os atributos que não são apenas os da extensão, mas com a dificuldade de lhes dar atributos da alma. (N p.38)

Nem mesmo Merleau-Ponty pensa numa solução; o que interessa aqui é a tensão entre as duas inspirações. Há um ponto de inflexão a esta altura do curso: desaparece o desejo de se conciliar as duas perspectivas, encaminham-se as duas posições a um jogo de oposições e polaridades que estão

\begin{tabular}{|c|c|c|c|c|c|}
\hline intuitio & $\begin{array}{c}\text { ISSN } \\
1983-4012\end{array}$ & Porto Alegre & Vol.10- $\mathrm{N}^{\circ} .2$ & $\begin{array}{c}\text { Dezembro } \\
2017\end{array}$ & p. 130-156 \\
\hline
\end{tabular}


Uma difícil aproximação: esboços da presença cartesiana no curso sobre a Natureza de Merleau-Ponty

permanentemente em vias de se resolver ou de se complicar. A aparição de Guéroult oferece uma possível solução através da razão, que logo em seguida é derrubada pela experiência real do sentimento.

A apropriação crítica se inverte; à produtividade inerente à Natureza acrescenta-se o problema do sujeito, ele próprio fonte e produção de sentido, posto que é terreno da teleologia. O sujeito que emerge dessas reflexões é bem mais próximo da concepção merleau-pontyana, pois nele "tudo é instituído pela Natureza de tal maneira que, quando tenho tal disposição dos músculos, tenho uma visão normal do objeto" $^{46}$ (N, p.38). Desaparece a distinção entre alma e pensamento e o corpo é restituído ao que Merleau-Ponty chama de pré-objetivo, no qual, tomado como uma totalidade dinâmica, encontra-se em interdependência e intercomunicação com o mundo sensível. Nesta perspectiva "o pensamento, nesta percepção da distância, se coloca a serviço do corpo, funciona a partir da disposição da máquina nervosa. [...] Estamos longe da ascese cartesiana que rejeitara o corpo fora de nós" (N, p.38).

Porém, do lado de Descartes permanece um ranço de irracionalismo que ousa se contrapor a uma filosofia assentada sobre o mais rigoroso dos racionalismos. A união substancial pode ser pensada e atestada pelo pensamento em situação, mas, em si, não há qualquer mudança nas substâncias implicadas no fenômeno, tampouco qualquer tentativa de fusão (ainda que parcial) ou entrecruzamento de pensamento e extensão. O corpo para Descartes, argumenta Merleau-Ponty, ainda é um corpo: pedaço de extensão, ele é regido pelas leis da física e se forma mecanicamente, como as peças duma máquina, sem qualquer traço de teleologia. A finalidade se restringe ao pensamento apenas. Mais do que isso: a mistura só é vivida pelo sujeito que a pensa, enquanto os outros corpos são apenas autômatos, e se há ação da alma nesses fragmentos de extensão é através dos efeitos da glândula pineal. Dum filósofo convicto de suas teses e partidário da mais metódica e rígida razão, Descartes passa a ser indeciso, um pensador relutante,

\footnotetext{
${ }^{46}$ Aqui Merleau-Ponty introduz a noção de julgamento natural, que ocorreria quando alma e corpo se cruzassem num mesmo ato, como no caso da percepção visual. Um julgamento natural a princípio seria um conceito que embaralharia duas posições que tradicionalmente são tomadas como opostas: o julgamento se relacionaria diretamente a uma filosofia idealista, enquanto que à natureza compete o caráter antagônico do realismo e do empirismo filosóficos. Numa das posturas, o sujeito é pura interioridade; na outra, ele está puramente do lado de fora de sua consciência. Merleau-Ponty se inspira em Malebranche para elaborar tal noção. Mas qual é a sua intenção ao se aproximar do padre parisiense, a ponto mesmo de lhe dedicar outro curso? É a restituição da atitude natural (no sentido husserliano) que Merleau-Ponty quer destacar na filosofia malebranchiana, e é por isso que o julgamento natural é evocado: "Malebranche dá conta da atitude natural do homem. Estou naturalmente orientado em direção ao mundo, ignorante de mim mesmo. Só sei por experiência que posso pensar o passado; minha memória não me é conhecida pela captura direta duma operação. Minha referência ao passado não é minha obra. Eu a obtenho: certas lembranças me são dadas. Não sou então um espírito que domina e desdobra o tempo, mas um espírito que dispõe de alguns poderes, dos quais desconhece a natureza. Não sei nunca o quanto valho, se sou justo ou injusto. Há então um aspecto pelo qual sou verdadeiramente dado a mim mesmo, e não como um princípio de mim mesmo. Não há claridade para mim que não implique uma obscuridade, e esta obscuridade sou eu mesmo (UAC, p.22). A rigor, o que o pensamento de Descartes tem de privativo e fechado, Malebranche tem de livre e aberto. Mais do que isso, o Cogito malebranchiano não é constituinte: ele conta com o mundo, mas não o põe. A obscuridade se infiltra ao descobrir que o pensamento não é coincidência consigo mesmo, mas sim reflexão sobre um fundo heterogêneo ao sujeito. O sujeito, mais propriamente aquele em que a alma e o corpo estão entrelaçados, é essa nódoa ou mancha de obscuridade que se infiltra no mundo racional criado e sustentado pelo infinito. Este é o impasse que interessa a Merleau-Ponty.
}

\begin{tabular}{|c|c|c|c|c|c|}
\hline intuitio & $\begin{array}{c}\text { ISSN } \\
1983-4012\end{array}$ & Porto Alegre & Vol.10- No.2 & $\begin{array}{c}\text { Dezembro } \\
2017\end{array}$ & p. 130-156 \\
\hline
\end{tabular}


passando do método à hesitação temerosa, pois "não decide entre a dupla forma da ligação alma-corpo: para mim, a alma habita todo o corpo, para outrem a alma habita o corpo em um ponto [...]daí o irracionalismo da vida como contrapeso do racionalismo rigoroso, que só pode ser analítico" (N, p.39).

A leitura de Merleau-Ponty ilumina duas faces de Descartes, ou dois momentos díspares em sua obra: um filósofo dotado da mais alta razão para fundamentar suas teses e constatações em um, em outro um pensador enredado em várias hipóteses e aporias para as quais não encontra soluções. Merleau-Ponty tende a criticar o primeiro e justificar o segundo: o que em Descartes é confusão, para ele é ambiguidade. Há uma mudança de léxico porque a leitura de Merleau-Ponty não despreza ou se afasta do problema, mas o coloca no centro. Diferentemente de Descartes, que dele se afasta, ou ostensivamente evita. Como toda apropriação crítica, há uma assimilação parcial do autor e de suas ideias, bem como o reconhecimento de suas imprecisões e das lacunas que se escondem nas entrelinhas.

\section{Conclusão}

A aproximação a Descartes feita nos primórdios do curso revela uma tessitura de avanços e recuos, de concórdia e discórdia, de crítica e assentimento por parte de Merleau-Ponty. Malgrado as imprecisões que se podem registrar no texto recolhido (fruto do cruzamento das anotações dos alunos e do plano de aulas original), Merleau-Ponty escolhe Descartes por ter inaugurado uma nova maneira de pensar a Natureza: pela primeira vez, o meio natural é afastado da concepção aristotélico-escolástica, abandonando uma perspectiva ontologicamente qualitativa, para se tornar um elemento capaz de ser quantificado e manejado pela razão humana. A partir de Descartes, os fenômenos e processos naturais podem ser atestados, medidos, registrados, calculados e arranjados. O que evidencia uma separação entre a razão e a Natureza: ambos se tornam heterogêneos e, em alguns momentos, até mesmo contrapostos.

No âmbito da obra merleau-pontyana, Descartes é o primeiro passo rumo a uma concepção de Natureza que fundamentará uma nova ontologia, baseada na reversibilidade entre o sujeito senciente e o estofo sensível do mundo. Contudo, na incursão cartesiana, Merleau-Ponty recupera duas inspirações que diferem muito entre si, que iluminam pontos conflitantes e opostos na mesma filosofia, e que, curiosamente, não são resolvidas durante as aulas. $\mathrm{O}$ andamento do curso sobre a Natureza manterá em suspenso o problema das duas inspirações cartesianas, que só serão retomadas muito à frente, no curso do biênio 1957-58.

Mais do que isso. Não há um esforço do próprio Merleau-Ponty em desenvolver e resolver o problema. A concepção é mantida tal como se apresenta, sem que se construa uma resposta à questão do humano e da finalidade. Isso tudo ocorre porque a aparição do homem não altera a primeira inspiração, que é, ademais, o principal conceito perseguido por Merleau-Ponty. É a tese num mundo racionalmente

\begin{tabular}{|c|c|c|c|c|c|}
\hline intuitio & $\begin{array}{c}\text { ISSN } \\
1983-4012\end{array}$ & Porto Alegre & Vol.10- $\mathrm{N}^{\circ} .2$ & $\begin{array}{c}\text { Dezembro } \\
2017\end{array}$ & p. 130-156 \\
\hline
\end{tabular}


criado e sustentado pelo infinito, um mundo tecido pela inteligibilidade, que Merleau-Ponty quer destacar, e com ele construir a sua própria noção de Natureza. O problema do humanismo acaba sendo uma questão lateral ou mesmo acessória.

As aulas sobre Descartes se encerram com uma conclusão lapidar: "Tal é o sentido constitutivo da ideia de Natureza: a Natureza decorre das propriedades do Deus infinito, isto é, uma vez que se pensou a Natureza do ponto de vista do naturante" (N, p.39). Qual seja: o essencial não é o ser humano, ele surge num segundo momento, quando o mundo natural já foi determinado e fixado pelas leis do entendimento, como "uma mancha no meio dum mundo inteligível luminoso" (N, p.40). Criterioso, Merleau-Ponty está longe de ser um detrator de Descartes; dele colhe alguns argumentos e questões pontuais, que serão aplicados em novos contextos enquanto elabora seu próprio pensamento. Mas se afasta de algumas outras questões, ou as retoma de modo fragmentado e parcial. Em outros casos, adota provisoriamente o método de leitura de outros comentadores e pega de empréstimo as suas teses, como no caso de Gueroult, presença constante e insistente. A leitura no âmbito do curso sobre a Natureza é seletiva, mas muito precisa: trata-se duma filosofia que busca subsídios na tradição a fim de enriquecer, tanto com questões quanto com respostas, a ontologia que ainda se apresentava como projeto. A ênfase neste primeiro momento é na letra cartesiana, nos rumos que as ideias e conceitos de Descartes foram tomando ao longo de seu assentamento na tradição.

\section{Referências}

BARBARAS, R. De l'être du phénomène: sur l'ontologie de Merleau-Ponty. Grenoble: Éditions Jérôme Millon, 2001.

. Merleau-Ponty et la Nature. In: BARBARAS, Renaud; BURKE, Patrick (org.). Chiasmi International 2. Paris/Milano/Memphis: Vrin/Mimesis/University of Memphis, 2000, n.2, p.47-62.

CHAUI, M. A Nervura do Real: imanência e liberdade em Espinosa. São Paulo: Companhia das Letras, 1999, v.1.

DESCARTES, R. Discurso do Método. Trad. de Maria Ermantina Galvão G. Pereira. São Paulo: Martins Fontes, 1996.

. Meditações sobre Filosofia Primeira. Trad. de Fausto Castilho. Campinas: UNICAMP, 2004.

. Princípios da Filosofia. Trad. de João Gama. Lisboa: Edições 70, 1997

DIOGÈNE LAËRCE. Vies et doctrines des philosophes illustres. Paris: Librairie Générale Française, 1999.

GUEROUlT, M. Descartes segundo a ordem das razões. Trad. de Érico Andrade et al. São Paulo: Discurso Editorial, 2016.

HUSSERL, E. Meditações Cartesianas e Conferências de Paris. Trad. de Pedro M. S. Alves. Rio de Janeiro: Forense, 2013.

MALEBRANCHE, N. Entretiens sur la métaphysique et sur la religion. In: Robinet, André (org.). Malebranche. Paris: Vrin, 1991, t.XII.

MERLEAU-PONTY, M. A Estrutura do Comportamento. Trad. de Márcia Valéria Martinez de Aguiar. São Paulo: Martins Fontes, 2006.

. La Nature. Notes. Cours du Collège de France. Paris: Éditions du Seuil, 1995.

. L'union de l'âme et du corps chez Malebranche, Biran e Bergson. Paris: Vrin, 2002.

Recebido em: 17/10/2017

Aprovado para a publicação em: 01/12/2017

\begin{tabular}{|c|c|c|c|c|c|}
\hline intuitio & $\begin{array}{c}\text { ISSN } \\
1983-4012\end{array}$ & Porto Alegre & Vol.10 - No.2 & $\begin{array}{c}\text { Dezembro } \\
2017\end{array}$ & p. 130-156 \\
\hline
\end{tabular}

